\title{
Solar access of residential rooftops in four California cities
}

\author{
Ronnen Levinson \\ Hashem Akbari \\ Melvin Pomerantz \\ Heat Island Group \\ Lawrence Berkeley National Laboratory \\ Smita Gupta \\ California Energy Commission
}

March 20, 2009

\begin{abstract}
Shadows cast by trees and buildings can limit the solar access of rooftop solar-energy systems, including photovoltaic panels and thermal collectors. This study characterizes residential rooftop shading in Sacramento, San Jose, Los Angeles and San Diego, CA. Our analysis can be used to better estimate power production and/or thermal collection by rooftop solar-energy equipment. It can also be considered when designing programs to plant shade trees.

High-resolution orthophotos and LiDAR (Light Detection And Ranging) measurements of surface height were used to create a digital elevation model of all trees and buildings in a welltreed $2.5-4 \mathrm{~km}^{2}$ residential neighborhood. On-hour shading of roofing planes (the flat elements of roofs) was computed geometrically from the digital elevation model. Values in future years were determined by repeating these calculations after simulating tree growth. Parcel boundaries were used to determine the extent to which roofing planes were shaded by trees and buildings in neighboring parcels.

For the subset of $\mathrm{S}+\mathrm{SW}+\mathrm{W}$-facing planes on which solar equipment is commonly installed for maximum solar access, absolute light loss in spring, summer and fall peaked about two to four hours after sunrise and about two to four hours before sunset. The fraction of annual insolation lost to shading increased from $0.07-0.08$ in the year of surface-height measurement to $0.11-0.14$ after 30 years of tree growth. Only about $10 \%$ of this loss results from shading by trees and buildings in neighboring parcels.
\end{abstract}




\section{Introduction}

Tree-planting programs designed to shade and cool the south or west sides of buildings can inadvertently limit the solar access of rooftop solar-energy systems, including photovoltaic panels and thermal collectors. Several researchers have modeled the influence of shade on the solar access of buildings. Kaye et al. [1] observed from the street the geometries of the roofs on and trees near 60 houses in an inner-city suburban region of Sydney, Australia. They then used ray-tracing software to predict the locations of on-hour shadows and estimate the average daily output of a nominally $1 \mathrm{~kW}$ rooftop photovoltaic array during winter months. Mardaljavec and Rylatt [2] applied the Radiance lighting-simulation system to a three-dimensional model of San Francisco to generate a map of annual insolation on modeled urban surfaces, including walls and roofs. Compagnon [3] also applied Radiance to three-dimensional building models to estimate urban solar availability, but presented results only for walls.

The CH2MHill Solar Automated Feature Extraction ${ }^{\mathrm{TM}}$ methodology [4] uses stereo aerial imagery to build three-dimensional model of buildings, then geometrically computes each building's solar access. The current version of this software does not consider trees because it is difficult to determine the heights of curved surfaces from stereo imagery.

Simpson [5] and Akbari [6] each modeled the influence of tree shading on residential energy use for heating and cooling. McPherson and Simpson [7] determined tree-canopy coverage from aerial photographs of 21 California cities to determine the extent to which tree planting programs could reduce energy use in California communities. Akbari et al. [8] and Rose et al. [9] also estimated urban tree cover from high-resolution orthophotos. However, none of these studies quantified shading of rooftops.

This paper estimates the extent to which shading reduces the solar radiation incident on residential roofs in the four California cities of Sacramento, San Jose, Los Angeles and San Diego. This shading analysis can be used to better estimate power production and/or thermal collection by rooftop solar-energy equipment. It can also be considered when designing programs to plant shade trees. 


\section{Methodology}

The locations and elevation profiles of buildings and trees is estimated by combining aerial photography with remote measurements of surface height. The fraction of each flat element of the roof's surface, or "roofing plane," that is shaded at a given hour of the year is determined by geometric computation of the extent to which trees and buildings obscure the path between the sun and the plane. This "shade fraction" gauges only the absence of direct sunlight. It does not distinguish between external shading and self shading and does not measure the absence of global (direct plus diffuse) sunlight.

We calculate two types of shading, "total" and "extraparcel." A plane's total shading is the fraction of its area that is shaded by any surface in the study region. A plane's extraparcel shading is the fraction of its area that is shaded by any surface outside the parcel that contains the plane.

Let "light loss" and "light-loss fraction" denote the absolute and relative reductions in solar access. Since interruption of the solar beam blocks all direct sunlight but little diffuse skylight, we define the plane's light loss (power per unit area) as the product of the shade fraction and the raw direct solar irradiance (power per unit area) that would be received by an unshaded reference surface of like orientation. The light-loss fraction is the ratio of light loss to raw global solar irradiance. Put another way, the light-loss fraction is the product of the "direct fraction" - the ratio of raw direct solar irradiance to raw global solar irradiance - and the shade fraction. The ratio of daily light loss (energy per unit area) to raw daily global solar irradiation (energy per unit area) is the daily light-loss fraction; the ratio of annual light loss to raw annual global solar irradiation is the annual light-loss fraction.

Light loss in future years is estimated by repeating these calculations after simulating tree growth.

\subsection{Spatial data selection}

A well-treed residential neighborhood in each city containing a mix of single- and double-story tract homes built between 1980 and 1990 was selected. This provided study regions in which trees were about 20 years old when surface elevations were measured (2001 or 2005) and thus tall enough to shade the roofs of these typical modern homes. Google Earth aerial images of the study regions in Sacramento $\left(2.7 \mathrm{~km}^{2}\right)$, San Jose $\left(4.1 \mathrm{~km}^{2}\right)$, Los Angeles $\left(3.7 \mathrm{~km}^{2}\right)$ and San Diego $\left(3.1 \mathrm{~km}^{2}\right)$ are 
shown in Figure 1.

\section{$2.2 \quad$ Tree surveys}

Urban tree surveys performed by city agencies, utilities, shade tree advocacy programs and urban foresters typically do not identify those trees that are both sufficiently close and tall enough to shade a roof. We conducted our own surveys by taking an expert arborist on a driving tour through about half of the streets in each study region. The arborist identified the species of each tree that we considered large enough and close enough to a house to possibly shade the roof. A limitation of this method is that we could clearly observe only the trees in the front or sides of the houses; we had no access to the backyards. However, most homes seemed to be on small lots with some lawn in front. This suggests that the back yards would tend to be too small for large trees.

Table 2 compiles the tree censuses performed in each of the four study regions. Also shown for each specie is the maximum height, growth rate and crown shape obtained from SelecTree tree selection guide [10] or from the Canopy tree library [11]. If there was a choice of subspecies, such as varieties of Ficus (fig) trees, we list the largest and fastest growing variety.

\subsection{Spatial data acquisition}

High-resolution digital color orthophotos and LiDAR (Light Detection And Ranging) measurements of surface elevation - i.e., height above sea level versus easting and northing - were collected by airplane-mounted instruments; parcel outlines were acquired from cities and counties (Table 1).

\subsection{Shading analysis}

The following analysis employed the ESRI ArcView 9.1 geographic information system (GIS) tool $[12]$.

\subsubsection{Roof, plane and tree outlines}

The shapes (ground-plane projection outlines) of all roofs, planes and tree canopies were manually traced from high resolution color orthophotos rendered in the GIS tool. Figures 2 shows roof, plane, tree and parcel borders overlaid on a detail of the San Jose study region. 


\subsubsection{Elevation and height rasters}

The year of the LiDAR survey - 2001 in Sacramento, 2005 elsewhere - is denoted year zero. A year-zero raster of surface elevation (surface height above sea level) spanning the study region was computed via inverse-distance-weighted interpolation of the LiDAR surface elevation measurements (Figure 3). All generated rasters contain square cells $50 \mathrm{~cm}$ on a side.

A ground-elevation raster (ground height above sea level) was computed as the 50-m focal minimum of the surface-elevation raster and the surface-height raster (surface height above ground) was computed by subtracting the ground-elevation raster from the surface-elevation raster. The study-region surface-elevation raster was then disaggregated by parcel to create a set of several thousand "parcel" surface-elevation rasters.

Additional rasters of surface elevation were constructed to account for tree growth after 10, 20 and 30 years. Tree height $h$ at age $t$ was approximated with the asymptotic growth model

$$
h(t)=H[1-\exp (-t / \tau)]
$$

where $H$ is the mature height of the tree. In this model, the time constant $\tau$, or age at which the tree reaches about $63 \%$ of its mature height, is equal to the ratio of the tree's mature height $H$ to its initial growth rate. Tree-canopy width was not increased over time in our analysis.

If the height of the tree at age $t_{0}$ is known to be $h_{0}$, the time constant $\tau$ can be eliminated from Eq. (1) to yield

$$
h(t)=H\left[1-\left(1-h_{0} / H\right)^{t / t_{0}}\right] .
$$

Assuming that all trees were planted when the homes were built made them about 20 years old in year zero. Each tree's height at this age was estimated as the maximum year-zero surface height-above-ground of cells within its traced border.

An upper limit to future-year shading was estimated with Eq. (2) by applying to all trees the mature height associated with the tallest species of trees found in the study regions $(H=20 \mathrm{~m})$. The relationship between future height $h(t)$ and initial height $h_{0}$ for trees with mature height $H$ $=20 \mathrm{~m}$ and initial age $t_{0}=20$ years is shown in Figure 5 . With these assumptions, any tree that is at least $10 \mathrm{~m}$ tall in year 0 will approach its mature height of $20 \mathrm{~m}$ by year 30 . Since the mean LiDAR-derived treetop height in year 0 was $10 \pm 4 \mathrm{~m}$ in Sacramento, $12 \pm 6 \mathrm{~m}$ in San Jose, $15 \pm 6 \mathrm{~m}$ 
in Los Angeles and $14 \pm 5 \mathrm{~m}$ in San Diego, the model predicts more tree growth in the Sacramento and San Jose than in Los Angeles and San Diego.

Future-year rasters of surface height above ground were generated by "growing" the trees in the year-zero raster of surface height above ground. Future-year surface elevation (above sea level) was then calculated by adding future-year surface height above ground to year-zero ground elevation.

\subsubsection{Plane aspect}

A vector was drawn to the centroid of each plane shape from the centroid of the roof shape containing that plane. The azimuthal angle of that vector was binned into a 45 -wide aspectN, NE, E, SE, S, SW, W or NW-indicating the side of the roof on which the plane lies. This method was found to be more reliable than determining aspect by fitting a planar surface through the subset of LiDAR points that lie above the plane's shape.

Table 3 shows the distribution of planes by aspect in each study region.

\subsubsection{Shadow rasters}

The National Renewable Energy Laboratory's Solar Position and Intensity (SOLPOS) calculator [13] was used to compute on-hour solar positions at the center of the study area to within $0.01^{\circ}$. The Hillshade function of the GIS tool was then used to determine from solar position whether any cell in a surface elevation raster lay in shadow. For each daylight hour in the 21st day of each month (143 hours/year), a raster of "total" shading - value 1 if the cell lies in the shadow of any cell in the study region; 0 otherwise - was computed from the study-region surface-elevation raster. Figure 6 illustrates on-hour total shading in San Jose at 9A, 12P, 3P and 5P local standard time (LST) on June 21.

A second raster of "intraparcel" shading — value 1 if the cell lies in the shadow of another cell within its own parcel; 0 otherwise - was generated by aggregating shadow rasters computed from the individual parcel surface-elevation rasters. Intraparcel shadow rasters were computed for only 15 hours/year - the daylight subsets of 9A, 12N,3P and 6P LST on the 21st days of March, June, September and December - because the time required to calculate intraparcel shading was about three orders of magnitude longer than that required to compute total shading. Figure 7 shows intraparcel shading in San Jose at 5P LST on June 21. 
On-hour "extraparcel" shadow rasters were computed by subtracting the on-hour intraparcel shadow rasters from the on-hour total shadow rasters (Figure 8). Scattered values of -1 (red cells) and 1 (black cells) in the extraparcel shadow raster are artifacts of the shadow modeling process that result from small registration errors.

\subsubsection{Shade fraction and light loss of each plane}

The on-hour total, intraparcel and extraparcel shade fractions of each roofing plane were computed by averaging the values of the plane's cells in the corresponding shadow raster. On-hour values of global-tilt solar irradiance (incident solar power/area) incident on unshaded, 5:12 pitch roofing planes in each of the eight aspects were computed with the Hay-Davies-Klutcher-Reindl radiation model [14] embedded in the California Energy Commission's CECPV 2.3 solar calculator [15]. On-hour values of the direct-tilt solar irradiance incidence on these surfaces were computed from consideration of solar position, plane orientation and the direct-normal solar irradiances values contained in the weather files bundled with the CECPV calculator. To reduce artifacts that can result from cloudy weather on a particular day, each on-hour irradiance was smoothed by calculating an hour-of-day running average over an interval of -15 days to +15 days.

Total, intraparcel and extraparcel instantaneous light losses (loss of incident solar power/area) were calculated by multiplying each on-hour shade fraction by the aspect-appropriate smoothed onhour direct-tilt solar irradiance. Corresponding instantaneous light-loss fractions were computed by dividing each light loss by the aspect-appropriate smoothed on-hour raw global-tilt solar irradiance.

\subsubsection{Light loss and light-loss fraction of a set of planes}

The on-hour mean light-loss fraction of a set of roofing planes, or fraction by which shading reduces the aggregate solar power incident on the planes at that hour, is the ratio of the planes' aggregate light loss - set sum of the product of each plane's on-hour shade fraction, on-hour raw direct-tilt solar irradiance and surface area - to the planes' aggregate raw global-tilt solar irradiance (set sum of the product of each plane's on-hour raw global-tilt solar irradiance and surface area). On-hour mean total, intraparcel and extraparcel light-loss fractions were computed for the subsets of roofing planes in each of the eight aspects.

The mean light-loss fraction $F$ of a set of roofing planes over some time interval, or fraction by 
which shading reduces the aggregate solar energy incident on these planes, is the ratio of the time integral of the planes' aggregate light loss to the time integral of the planes' aggregate raw globaltilt solar irradiance. Daily mean total light-loss fractions for the subsets of roofing planes in each of the eight aspects were evaluated the 21st day of each month. Intraparcel and extraparcel values were evaluated on the 21st days of March, June, September and December. Annual mean lightloss fractions were evaluated by integrating over all hours of the year for which on-hour light-loss fractions were computed.

\subsubsection{Solar access violation}

California Public Resources Code $\S 25982$ [16] states that, subject to certain exceptions,

...no person owning, or in control of a property shall allow a tree or shrub to be placed, or, if placed, to grow on such property, subsequent to the installation of a solar collector on the property of another so as to cast a shadow greater than 10 percent of the collector absorption area upon that solar collector surface on the property of another at any one time between the hours of 10 a.m. and 2 p.m., local standard time...

The solar access of a roofing plane was considered violated in a given month if its extraparcel shade fraction exceeded $10 \%$ at any time between 10A and 2P LST on the 21st day of that month. Since extraparcel shading was calculated only at 9A, 12N, 3P and - except in December-6P LST, extraparcel shade fractions at 10A, 11A, 1P and 2P LST were interpolated from the calculated values.

\section{Results}

\subsection{Special characteristics of S-, SW- and W-facing planes}

The following analysis pays special attention to the "S+SW+W" subset of roofing planes that face $\mathrm{S}$, SW or W, because solar equipment is commonly installed on such planes for maximum solar access. For example, assuming a plane slope of 5:12, annual mean raw global solar irradiance in the four study regions is greatest for S-facing planes; values for SW-, SE-, W- and E-facing planes are $3-5 \%, 5-7 \%, 10-15 \%$ and $15-20 \%$ lower, respectively (Figure 9). However, the raw global solar irradiances received by SW- and W-facing planes can exceed that incident on a S-facing planes 
during times of peak electrical demand, such as late afternoon in summer. We note also that daily mean global solar irradiance on $\mathrm{S}+\mathrm{SW}+\mathrm{W}$-facing planes on December 21 (the winter solstice) is only about $30 \%$ of that on June 21 (the summer solstice).

The S-, SW- and W-facing planes in the four regions generally have higher direct fractions - that is, receive greater proportions of their global solar irradiances in the form of direct sunlight - than do planes of other orientations (Figure 10). Since light-loss fraction is the product of shade fraction and direct fraction, these high values of direct fraction can in some circumstances make the light-loss fraction of a S-, SW- or W-facing plane exceed that of, say, a N-facing plane.

\subsection{On-hour light-loss fractions and light losses of $\mathrm{S}+\mathrm{SW}+\mathrm{W}$-facing planes in years 0 and 30}

Since direct fraction increases and shadow length decreases with solar altitude, on-hour total lightloss fraction (shade fraction times direct fraction) was typically lowest near sunrise and sunset, when direct fraction is small and around noon, when shadows are shortest. On-hour total lightloss fractions typically peaked about one to two hours after sunrise and one to two hours before sunset (Figure 11). In year 0, the maximum values of on-hour total light-loss fraction were 0.43 in Sacramento, 0.44 in San Jose, 0.25 in Los Angeles and 0.55 in San Diego. In year 30, they reached 0.46 in Sacramento, 0.47 in San Jose, 0.34 in Los Angeles and 0.58 in San Diego. Between year 0 and year 30, individual on-hour total light-loss fractions increased by up to 0.15 in Sacramento, 0.13 in San Jose, 0.09 in Los Angeles and 0.14 in San Diego.

On-hour total light loss (shade fraction times direct solar irradiance) vanished at sunrise and sunset, when there was no direct sunlight. On the spring, summer and autumn days, on-hour total light loss typically peaked about two to four hours after sunrise and about two to four hours before sunset, with a midday trough near noon. On the winter day, the shapes of the on-hour total light loss curves were complicated by the influence of cloudy weather on direct solar irradiance (Figure 11). In year 0 , the maximum values of on-hour total light loss were $71 \mathrm{~W} \mathrm{~m}^{-2}$ in Sacramento, $65 \mathrm{~W}$ $\mathrm{m}^{-2}$ in San Jose, $85 \mathrm{~W} \mathrm{~m}^{-2}$ in Los Angeles and $72 \mathrm{~W} \mathrm{~m}^{-2}$ in San Diego. In year 30, they reached $140 \mathrm{~W} \mathrm{~m}^{-2}$ in Sacramento, $109 \mathrm{~W} \mathrm{~m}^{-2}$ in San Jose, $125 \mathrm{~W} \mathrm{~m}^{-2}$ in Los Angeles and $115 \mathrm{~W} \mathrm{~m}^{-2}$ in San Diego. Between year 0 and year 30, individual on-hour total light losses increased by up to $78 \mathrm{~W} \mathrm{~m}^{-2}$ in Sacramento, $45 \mathrm{~W} \mathrm{~m}^{-2}$ in San Jose, $46 \mathrm{~W} \mathrm{~m}^{-2}$ in Los Angeles and $48 \mathrm{~W} \mathrm{~m}^{-2}$ in San 
Diego.

On-hour extraparcel light-loss fractions were very small in year 0; all values were less than 0.05 except for two peaks of about 0.13 . In year 30 , all values were less than 0.10 , except for two peaks of 0.15. Between year 0 and year 30, individual extraparcel light-loss fractions increased by up to 0.05 in Sacramento, 0.04 in San Jose, 0.03 in Los Angeles and 0.04 in San Diego. On-hour extraparcel light losses were also very small, never exceeding $10 \mathrm{~W} \mathrm{~m}^{-2}$ in year 0 and $25 \mathrm{~W} \mathrm{~m}^{-2}$ in year 30 . Between year 0 and year 30, individual extraparcel light losses increased by up to $15 \mathrm{~W} \mathrm{~m}^{-2}$ in Sacramento, $11 \mathrm{~W} \mathrm{~m}^{-2}$ in San Jose, $8 \mathrm{~W} \mathrm{~m}^{-2}$ in Los Angeles and $16 \mathrm{~W} \mathrm{~m}^{-2}$ in San Diego.

\subsection{Daily light-loss fractions for $\mathrm{S}+\mathrm{SW}+\mathrm{W}$-facing planes in years $0,10,20$ and 30}

Figure 12 plots for each study region the daily total and extraparcel light-loss fractions for the $\mathrm{S}+\mathrm{SW}+\mathrm{W}$ subset of planes on the 21st day of each month in years $0,10,20$ and 30.

Daily light-loss fractions are greatest in winter and least in summer because at a given hour of the day, the sun is lower and shade fractions are greater - that is, shadows are longer-in winter than in summer. However, since light-loss fraction is the product of shade fraction and direct fraction, seasonal variations in direct fraction (Figure 10) can augment or decrease daily light-loss fractions. For example, the $\mathrm{S}+\mathrm{SW}+\mathrm{W}$ set of planes in Sacramento receives $78 \%$ of its global solar irradiance as direct sunlight on June 21 , but only $63 \%$ on December 21 , diminishing the wintersummer difference in light-loss fraction. San Jose has a similar pattern, with direct fractions of $78 \%$ on June 21 and $60 \%$ on December 21 . Variations in direct fraction tend to increase the wintersummer differences in light-loss fraction in Los Angeles and San Diego, where direct fractions are lower in summer than in winter (64\% vs. $72 \%$ in Los Angeles, $65 \%$ vs. $79 \%$ in San Diego). These effects make the Los Angeles and San Diego light-loss fraction curves in Figure 12 more elliptical than those for Sacramento and San Jose.

Over the course of the year, daily total light-loss fractions of $\mathrm{S}+\mathrm{SW}+\mathrm{W}$ planes in year 0 were 0.05 - 0.14 in Sacramento, $0.05-0.15$ in San Jose, $0.05-0.15$ in Los Angeles and $0.04-0.16$ in San Diego; the range over all regions was $0.04-0.16$. By year 30, values increased to $0.09-0.26$ in Sacramento, 0.08 - 0.23 in San Jose, $0.07-0.23$ in Los Angeles and 0.05 - 0.25 in San Diego; the range over all regions was $0.06-0.25$. 
Daily extraparcel light-loss fractions of $\mathrm{S}+\mathrm{SW}+\mathrm{W}$ planes in year 0 were $0.00-0.03$ in Sacramento, 0.01 - 0.02 in San Jose, 0.00 - 0.01 in Los Angeles and 0.00 - 0.01 in San Diego; the range over all regions was $0.00-0.03$. By year 30, values increased to $0.01-0.06$ in Sacramento, 0.01 0.05 in San Jose, 0.01 - 0.03 in Los Angeles and 0.01 - 0.04 in San Diego; the range over all regions was $0.01-0.06$.

\subsection{Daily light-loss fractions by aspect in years 0 and 30}

Figures 13 and 14 plot for each study region the daily total and extraparcel light-loss fractions by aspect on March 21, June 21, September 21 and December 21 in years 0 and 30, respectively.

The shape of each curve of daily light-loss fraction versus aspect depends on the hourly solar trajectory, the hourly direct fraction and surface topography - that is, the relative heights and locations of buildings and trees. The solar trajectory in Sacramento (latitude $38.5^{\circ} \mathrm{N}$ ) is similar to that in San Jose (latitude $37.3^{\circ} \mathrm{N}$ ) and the solar trajectory in Los Angeles (latitude $34.0^{\circ} \mathrm{N}$ ) is similar to that in San Diego (latitude $33.0^{\circ} \mathrm{N}$ ). There is some similarity between the hourly direct fractions in Sacramento and San Jose and little between the hourly direct fractions for any other pair of cities (Figure 10). There is no reason to expect the surface topographies in any two cities to be alike. Hence, it is unsurprising that the curves of daily light-loss fraction versus aspect differ strongly from city to city in Figures 13 and 14.

Daily light-loss fractions in every aspect were generally smallest in summer and largest in winter, with intermediate values in spring and autumn. Two prominent features in these curvesthe autumn-spring differences in daily light loss fractions and the dips in light-loss fraction on December 21 for N-facing planes - can be traced to the charts of direct fraction versus aspect shown in Figure 10.

Over the four study regions, year 0 daily total light-loss fractions by aspect were 0.03 - 0.08 on June 21, 0.06 - 0.14 on March 21, 0.05 - 0.12 on September 21 and 0.06 - 0.20 on December 21. In year 30, these values increased to $0.05-0.11$ on June 21, $0.10-0.17$ on March 21, $0.08-0.16$ on September 21 and 0.07 - 0.26 on December 21. Year 0 daily extraparcel light-loss fractions were 0.00 - 0.01 on June 21, 0.00 - 0.02 on March 21, 0.00 - 0.01 on September 21 and 0.00 - 0.03 on December 21. In year 30, these values increased to 0.00 - 0.02 on June 21, 0.00 - 0.03 on March 21, 0.00 - 0.02 on September 21 and 0.00 - 0.06 on December 21 . 
For the subset of $\mathrm{S}+\mathrm{SW}+\mathrm{W}$-facing planes in the four study regions, year 0 daily total light-loss fractions were 0.04 - 0.06 on June 21, 0.07 - 0.10 on March 21, 0.06 - 0.08 on September 21 and 0.14 - 0.16 on December 21. In year 30, these values increased to 0.05 - 0.09 on June 21, 0.11 - 0.14 on March 21, 0.09 - 0.15 on September 21 and 0.23 - 0.26 on December 21. Year 0 daily extraparcel light-loss fractions were 0.00 - 0.01 on June 21, March 31 and September 21 and $0.01-0.03$ on December 21. In year 30, these values increased to 0.00 - 0.01 on June 21, 0.01 - 0.02 on March 21 and September 21 and 0.03 - 0.06 on December 21.

\subsection{Annual light-loss fractions by aspect in years 0, 10, 20 and 30}

Figure 15 plots for each study region the annual total and extraparcel light-loss fractions by aspect in years $0,10,20$ and 30. Differences in hourly solar trajectory, hourly direct fraction and surface topography all tend to make curves of annual light-loss fraction in each year vary from region to region. However, the most prominent feature in this figure - that light-loss fractions increased more from year 0 to year 30 in Sacramento and San Jose than in Los Angeles and San Diego-resulted from greater tree growth in the first two cities (c.f. $\S 2.4 .2$ ).

Over the four study regions, annual total light-loss fractions by aspect were $0.06-0.10$ in year 0, $0.08-0.12$ in year 10, $0.09-0.13$ in year 20 and $0.09-0.14$ in year 30. Annual extraparcel light-loss fractions were $0.00-0.01$ in year 0 and $0.00-0.02$ in years 10,20 and 30 .

For the subset of $\mathrm{S}+\mathrm{SW}+\mathrm{W}$-facing planes in the four study regions, annual total light-loss fractions were $0.07-0.08$ in year $0,0.09-0.10$ in year $10,0.10-0.12$ in year 20 and $0.11-0.14$ in year 30. Annual extraparcel light-loss fractions were 0.01 in years 0 and 10 and 0.01 - 0.02 in years 20 and 30.

\subsection{Daily solar access violations by aspect}

Figures 16 and 17 plot for each study region the rates of solar access violation by aspect on March 21, June 21, September 21 and December 21 in years 0 and 30, respectively.

Rates of solar access violation were much higher on December 21 than on the three other days because the sun is low and mid-day shadows are long in winter. Over the four study regions, year 0 rates of solar access violation by aspect were $0-3 \%$ on June $21,1-7 \%$ on March 21, $1-6 \%$ on September 21 and 4 - 31\% on December 21. By year 30, these values increased to 0 - $4 \%$ on June 
21, 2 - 19\% on March 21, 3 - 20\% on September 21 and $12-56 \%$ on December 21.

For $\mathrm{S}+\mathrm{SW}+\mathrm{W}$-facing planes, year 0 rates of solar access violation were $1 \%$ on June $21,2-5 \%$ on March 21, 3-5\% on September 21 and $11-28 \%$ on December 21. By year 30, these values increased to $1-3 \%$ on June 21, 6 - 16\% on March 21, $7-16 \%$ on September 21 and $29-55 \%$ on December 21.

\section{Conclusions}

Tree growth increased annual total light-loss fractions for the $\mathrm{S}+\mathrm{SW}+\mathrm{W}$-facing planes by about 50 to $70 \%$ over 30 years, from $0.07-0.08$ in year 0 to $0.11-0.14$ in year 30. Annual extraparcel light-loss fractions very slightly increased from 0.01 in years 0 to $0.01-0.02$ in year 30. Trees and buildings in neighboring parcels are responsible for only about $10 \%$ of the annual light loss of these roofing planes (i.e., annual extraparcel shade fraction / annual total shade fraction $\approx 10 \%$ ).

Shading degrades solar access least in summer, which abets the production of electricity to meet peak demand in the cooling season. For example, daily total light-loss fractions for $\mathrm{S}+\mathrm{SW}+\mathrm{W}-$ facing planes in year 0 were $0.04-0.06$ on June 21 and $0.14-0.16$ on December 21, increasing by year 30 to 0.05 - 0.09 on June 21 and 0.23 - 0.26 on December 21 .

Long winter shadows yield high rates of solar access violation on December 21. For example, year 0 rates of solar access violation for $\mathrm{S}+\mathrm{SW}+\mathrm{W}$-facing planes were 1\% on June 21 and $11-28 \%$ on December 21, increasing by year 30 to $1-3 \%$ on June 21 and $29-55 \%$ on December 21. High rates of violation in winter do not greatly reduce annual solar access because the daily mean global solar irradiance on December 21 is less than a third of that on June 21.

In spring, summer and autumn, total light loss for $\mathrm{S}+\mathrm{SW}+\mathrm{W}$-facing planes peaks about two to four hours after sunrise and about two to four hours before sunset. In summer, the light loss fraction in late afternoon (when demand for cooling electricity is particularly high) is about twice the fraction of light lost over the entire day. For example, on June 21 of year 0 in San Jose, the light loss fraction at 5P LST is 0.12 , while that for the entire day is 0.06 . This suggests that daily or annual light loss fractions may not properly capture the influences of shading on solar access during peak demand hours. Future work could gauge the economic losses that result from shading by weighting hourly light loss with the time-dependent value of electricity. 


\section{Acknowledgements}

This work was supported by the California Energy Commission (CEC) through its Public Interest Energy Research Program (PIER) and by the Assistant Secretary for Energy Efficiency and Renewable Energy under Contract No. DE-AC02-05CH11231. We thank Bill Pennington of the California Energy Commission for helping to organize the study and for his guidance and support. For identifying trees, we thank Dan Pskowski, arborist, City of Sacramento; Ralph Mize, arborist, City of San Jose; David Lofgren, arborist, Los Angeles County Arboretum; and Drew Potocki, arborist, City of San Diego. For providing spatial data, we thank Nathan Jennings, City of Sacramento; Kevin Briggs and Roland Gong, City of San Jose; and Lisa Lubeley, City of San Diego. Finally, we thank Kimberly Fujita for tracing the outlines of roughly 100,000 roofs, planes and trees in our study-region images.

\section{References}

[1] R.J. Kaye, R. O’Brien, N. Ghiotto, and P. McKee. Site selection and assessment of rooftop photovoltaic installations. In Proceedings of the 14th European Photovoltaic Solar Energy Conference and Exhibition, Barcelona, Spain, 30 June - 4 July 1997.

[2] J. Mardaljevic and M. Rylatt. Irradiation mapping of complex urban environments: an imagebased approach. Energy \& Buildings, 35:27-35, 2003.

[3] R. Compagnon. Solar and daylight availability in the urban fabric. Energy $\&$ Buildings, $36: 321-328,2004$.

[4] CH2MHill. CH2MHill Solar Automated Feature Extraction TM technology. http://www . ch2m. com, 2008.

[5] J.R. Simpson. Improved estimates of tree-shade effects on residential energy use. Energy \& Buildings, 34:1067-1076, 2002.

[6] H. Akbari. Shade trees reduce building energy use and $\mathrm{CO}_{2}$ emissions from power plants. Environmental Pollution, 116:S119-S126, 2002. 
[7] E.G. McPherson and J.R Simpson. Potential energy savings in buildings by an urban tree planting programme in California. Urban Forestry \& Urban Greening, 2:73-86, 2003.

[8] H. Akbari, L.S. Rose, and H. Taha. Analyzing the land cover of an urban environment using high-resolution orthophotos. Landscape \& Urban Planning, 63:1-14, 2003.

[9] L.S. Rose, H. Akbari, and H. Taha. Characterizing the fabric of the urban environment: a case study of greater Houston, Texas. Report LBNL-51448, Lawrence Berkeley National Laboratory, Berkeley, CA, 2003.

[10] UFEI. Selectree: a tree selection guide. http://selectree.calpoly.edu, 2008. Urban Forests Ecosystem Institute, California Polytechnic State University, San Luis Obispo, CA.

[11] Canopy. Canopy tree library. http://www. canopy.org, 2008. Palo Alto, CA.

[12] ESRI. ESRI ArcView 9.1 geographic information system. http://www.esri.com, 2008.

[13] NREL MIDC. National Renewable Energy Laboratory Measurement and Instrumentation Data Center (NREL MIDC) Solar Position and Intensity (SOLPOS) Calculator. Online at http://www.nrel.gov/midc/solpos/solpos.html, 2008.

[14] J.A. Duffie and W.A. Beckman. Solar Engineering of Thermal Processes. John Wiley \& Sons, 3rd edition, 2006.

[15] B.A. Wilcox and W.A. Beckman. California Energy Commission CECPV Calculator 2.3. http: //www.gosolarcalifornia.ca.gov/nshpcalculator/download_calculator.html, 2008.

[16] CPRC. California Public Resources Code $§ 25982$. http://www.leginfo.ca.gov/cgi-bin/ displaycode?section=prc\&group=25001-26000\&file=25980-25986, 2008. 


\begin{tabular}{|c|c|c|c|c|}
\hline & Sacramento & San Jose & Los Angeles & San Diego \\
\hline area $\left(\mathrm{km}^{2}\right)$ & 2.7 & 4.1 & 3.7 & 3.1 \\
\hline center & $38.50^{\circ} \mathrm{N}$ & $37.31^{\circ} \mathrm{N}$ & $34.03^{\circ} \mathrm{N}$ & $32.96^{\circ} \mathrm{N}$ \\
\hline & $121.54^{\circ} \mathrm{W}$ & $121.78^{\circ} \mathrm{W}$ & $117.88^{\circ} \mathrm{W}$ & $117.14^{\circ} \mathrm{W}$ \\
\hline parcel count & 2,461 & 3,705 & 2,169 & 2,554 \\
\hline roof count & 2,411 & 3,610 & 2,120 & 2,538 \\
\hline plane count & 10,626 & 17,998 & 8,619 & 10,151 \\
\hline tree count & 7,263 & 11,200 & 11,588 & 9,304 \\
\hline parcel shape date & March 2005 & January 2006 & March 2006 & January 2006 \\
\hline parcel shape source & $\begin{array}{l}\text { City of Sacra- } \\
\text { mento }\end{array}$ & City of San Jose & $\begin{array}{l}\text { Los Angeles } \\
\text { County }\end{array}$ & $\begin{array}{l}\text { SanGIS (city and } \\
\text { county of San } \\
\text { Diego) }\end{array}$ \\
\hline orthophoto flight date & March 2001 & March 2001 & November 2005 & March - May 2005 \\
\hline orthophoto source & $\begin{array}{l}\text { Horizons, Inc. via } \\
\text { City of Sacra- } \\
\text { mento }\end{array}$ & $\begin{array}{l}\text { Triathlon Ltd. } \\
\text { via City of San } \\
\text { Jose }\end{array}$ & $\begin{array}{l}\text { Optimal Geomat- } \\
\text { ics }\end{array}$ & $\begin{array}{l}\text { Merrick and Com- } \\
\text { pany via City of } \\
\text { San Diego }\end{array}$ \\
\hline orthophoto pixel size $(\mathrm{cm})$ [in] & $\begin{array}{l}15.2 \times 15.2[6 \times \\
6]\end{array}$ & $7.6 \times 7.6[3 \times 3]$ & $7.6 \times 7.6[3 \times 3]$ & $7.6 \times 7.6[3 \times 3]$ \\
\hline LiDAR flight date & March 2001 & October 2005 & November 2005 & March - May 2005 \\
\hline LiDAR source & $\begin{array}{l}\text { Horizons, Inc. via } \\
\text { City of Sacra- } \\
\text { mento }\end{array}$ & Airborne1 & $\begin{array}{l}\text { Optimal Geomat- } \\
\text { ics }\end{array}$ & $\begin{array}{l}\text { Merrick and Com- } \\
\text { pany via City of } \\
\text { San Diego }\end{array}$ \\
\hline LiDAR horizontal spacing (m) & 4 & 1.4 & 0.87 & 1.5 \\
\hline LiDAR horizontal accuracy $(\mathrm{m})$ & 0.4 & 0.46 & 0.6 & 1.2 \\
\hline LiDAR vertical accuracy $(\mathrm{m})$ & 0.2 & 0.36 & 0.12 & 0.36 \\
\hline LiDAR points in study region & 338,279 & $8,308,823$ & $10,143,843$ & $4,797,743$ \\
\hline $\begin{array}{l}\text { LiDAR density (points } / \mathrm{m}^{2} \text { ) } \\
\text { notes }\end{array}$ & $\begin{array}{l}0.1 \\
\text { Pocket Road area }\end{array}$ & 2.0 & $\begin{array}{l}2.7 \\
\text { City of Walnut }\end{array}$ & 1.6 \\
\hline
\end{tabular}

Table 1: Characteristics of study regions in four California cities. 


\begin{tabular}{|c|c|c|c|c|c|c|c|}
\hline & $\begin{array}{l}\text { Maximum } \\
\text { height }(\mathrm{m})\end{array}$ & $\begin{array}{l}\text { Growth rate } \\
\text { (cm/season) }\end{array}$ & Crown shape & $\begin{array}{l}\text { Sacra- } \\
\text { mento }\end{array}$ & San Jose & $\begin{array}{l}\text { Los } \\
\text { Angeles }\end{array}$ & $\begin{array}{l}\text { San } \\
\text { Diego }\end{array}$ \\
\hline Alder White & 20 & 94 & conical & 3 & & 4 & 1 \\
\hline Ash, Evergreen & 20 & 94 & oval & & 1 & & 11 \\
\hline Ash, Raywood & 11 & 61 & oval & 2 & 3 & 1 & \\
\hline Ash, Shamel & 20 & 91 & oval & 1 & 3 & & \\
\hline Birch, N. European & 15 & 91 & oval & & & 1 & \\
\hline Birch - White & 15 & 91 & oval & 17 & 2 & & \\
\hline Bottlebrush & 8 & 91 & oval & & & 1 & \\
\hline Box, Brisbane & 15 & 91 & oval & & & & 8 \\
\hline Camphor & 20 & 61 & rounded & 2 & 1 & & \\
\hline Carrot Wood & 11 & 61 & oval & & & 9 & 2 \\
\hline Cedar, Blue Atlas & 20 & 61 & conical & & 1 & & \\
\hline Cedar, Deodar & $>20$ & 91 & conical & & 3 & & \\
\hline Cherry, Flowering & 8 & 91 & umbrella & 1 & & & \\
\hline Chinese Flame & 11 & 61 & rounded & & & & 1 \\
\hline Chinese Hackberry & 20 & 61 & rounded & 4 & & & \\
\hline Chinese Pistache & 20 & 61 & oval & & 1 & & \\
\hline Chinese Tallow & 11 & $61-91$ & conical & 5 & & & \\
\hline Crape Myrtle & 8 & 61 & oval & 1 & 1 & & \\
\hline Cypress, Italian & 15 & 91 & columnar & & 9 & 18 & 1 \\
\hline Cypress, Leyland & $>20$ & 91 & conical & & & & 6 \\
\hline Elm, Chinese & 20 & $>94$ & oval & & 3 & & \\
\hline Ericaceae (Madrone) & 20 & 61 & round & & & 6 & \\
\hline Eucalyptus, & $>20$ & $>94$ & oval & & 6 & 15 & 5 \\
\hline Ficus (Fig) & 20 & $>94$ & rounded & & & 8 & 1 \\
\hline Ginko & 20 & 91 & columnar & & & 1 & \\
\hline Honey Locust & 20 & 91 & oval & 3 & & & \\
\hline Jacaranda & 15 & 61 & oval & & 1 & 6 & 1 \\
\hline Juniper, California & 11 & 61 & conical & & & 2 & \\
\hline Liquidambar & 20 & 91 & conical & 8 & & 3 & \\
\hline London Plane & 20 & 91 & oval & 4 & 1 & & \\
\hline Magnolia & 20 & 61 & oval & 1 & 1 & 1 & \\
\hline Maple, Silver & 20 & $>94$ & oval & & 4 & & \\
\hline Oak, Coast Live & 20 & 61 & rounded & & 1 & & \\
\hline Oak, Red & 20 & $61-91$ & oval & 1 & & & \\
\hline Oak, Silk & 20 & 91 & oval & 1 & & & \\
\hline Oak, Valley & $>20$ & 91 & oval & & 2 & & \\
\hline Oak, Holly & 20 & 61 & rounded & 1 & 1 & & \\
\hline Palm, King & 20 & 61 & feather palm & & & 10 & 1 \\
\hline Palm, Mexican & $>20$ & $>94$ & fan palm & & & & 3 \\
\hline Palm, Queen & 15 & 91 & feather palm & & & & 2 \\
\hline Pear Ornamental (Aristocrat) & 15 & $61-91$ & conical & 2 & 1 & & \\
\hline Pepper, Californian & 15 & 91 & rounded & & 2 & 2 & \\
\hline Pine, Canary Island & 20 & 91 & columnar & & 3 & 1 & 15 \\
\hline Pine, Italian Stone & $>20$ & 91 & conical & & 1 & 10 & 2 \\
\hline Pine, Japanese Black & $15-20$ & $61-91$ & conical & 2 & & & \\
\hline Pine, Monterey & $>20$ & $>94$ & conical & & 4 & 8 & \\
\hline Pine, Norfolk Island & $>20$ & 61 & conical & & & & 1 \\
\hline Pine, Torrey & 20 & 91 & conical & & & & 3 \\
\hline Pittosporum & 11 & 61 & oval & & & 1 & \\
\hline Plum Purple Leaf & 11 & $61-91$ & oval & 1 & & & \\
\hline Podocarpus, Latifolius & 20 & 61 & conical & & & 4 & \\
\hline Privet, Glossy & 15 & 91 & oval & & 1 & & \\
\hline Redwood, Coast & $>20$ & 91 & conical & 7 & 12 & & \\
\hline Sequoia & $>20$ & 91 & conical & & & 1 & \\
\hline Sycamore, Ca, Yarwood & $>20$ & 91 & oval & & 2 & 6 & \\
\hline Tulip & 20 & 91 & conical & 1 & & & \\
\hline Walnut, CA Black & 20 & 61 & rounded & & 1 & & \\
\hline Willow, Australian & 11 & 91 & oval & & 1 & 1 & \\
\hline Total & & & & 68 & 73 & 120 & 64 \\
\hline
\end{tabular}

Table 2: Growth characteristics and counts of tree species cataloged in ground surveys. 


\begin{tabular}{|c|c|c|c|c|}
\hline & Sacramento & San Jose & Los Angeles & San Diego \\
\hline S+SW+W & 36.4 & 38.5 & 37.8 & 37.7 \\
S & 14.7 & 15.8 & 14.5 & 14.3 \\
SW & 11.6 & 12.1 & 12.4 & 12.0 \\
W & 10.2 & 10.7 & 11.0 & 11.4 \\
NW & 12.7 & 12.1 & 11.8 & 12.0 \\
N & 15.1 & 14.3 & 13.8 & 14.0 \\
NE & 12.3 & 11.7 & 12.3 & 11.7 \\
E & 11.5 & 10.6 & 11.6 & 12.3 \\
SE & 11.9 & 12.8 & 12.7 & 12.3 \\
\hline
\end{tabular}

Table 3: Fraction (\%) of planes by aspect in each study region. 

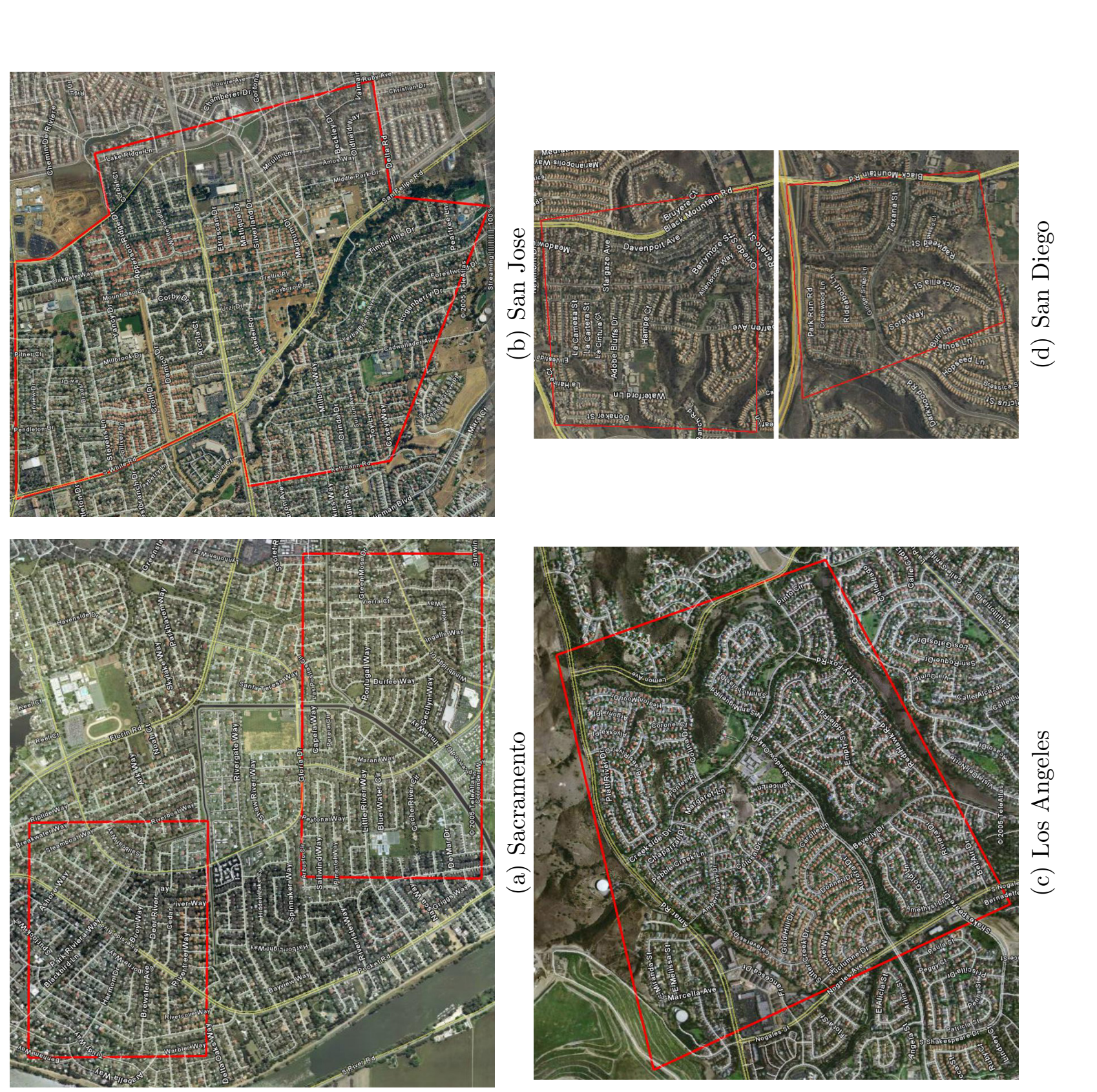

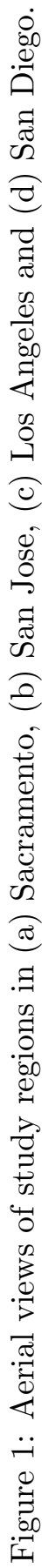




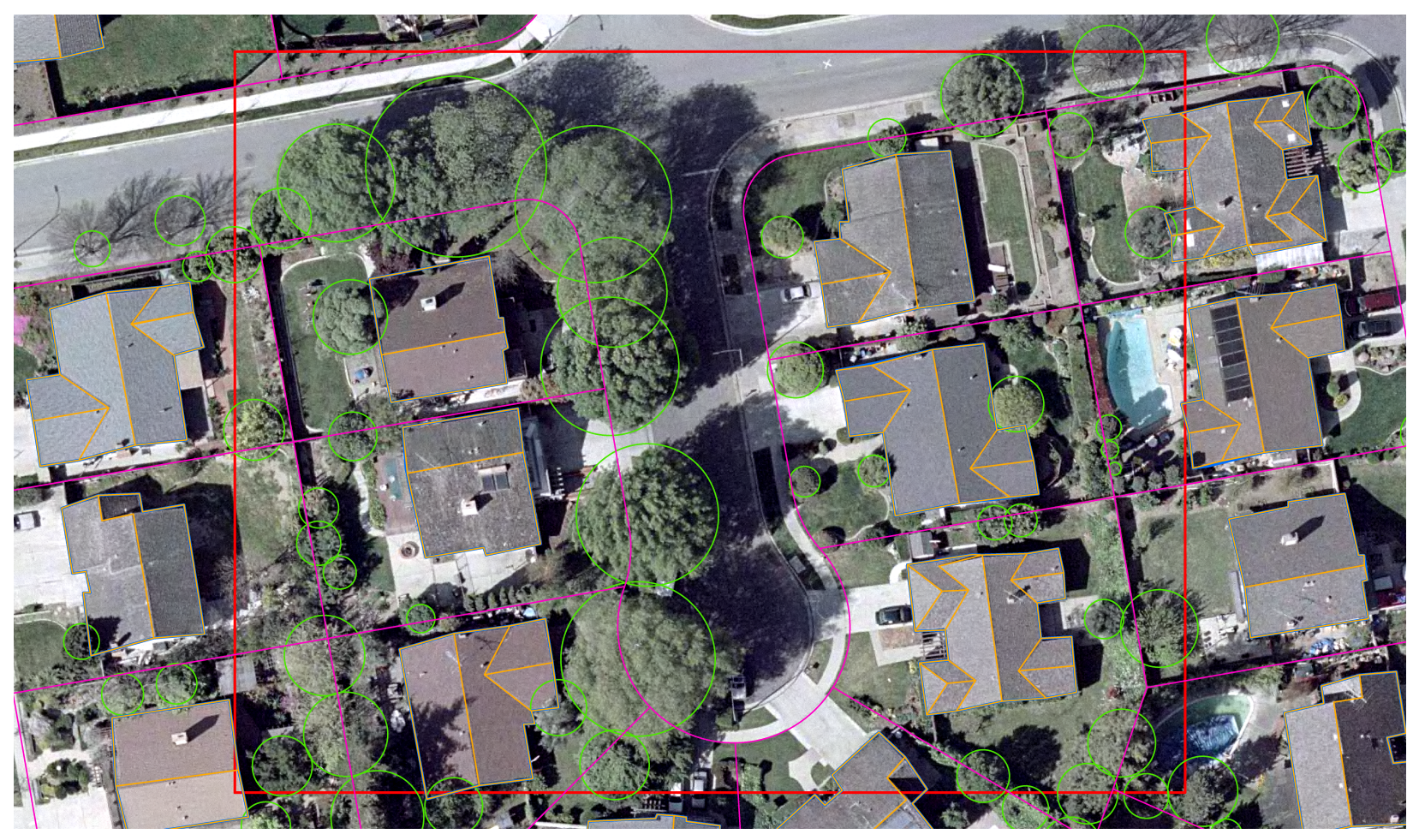

Figure 2: Roof (blue), plane (gold), tree (green) and parcel (magenta) shapes overlaid on detail of San Jose orthophoto.

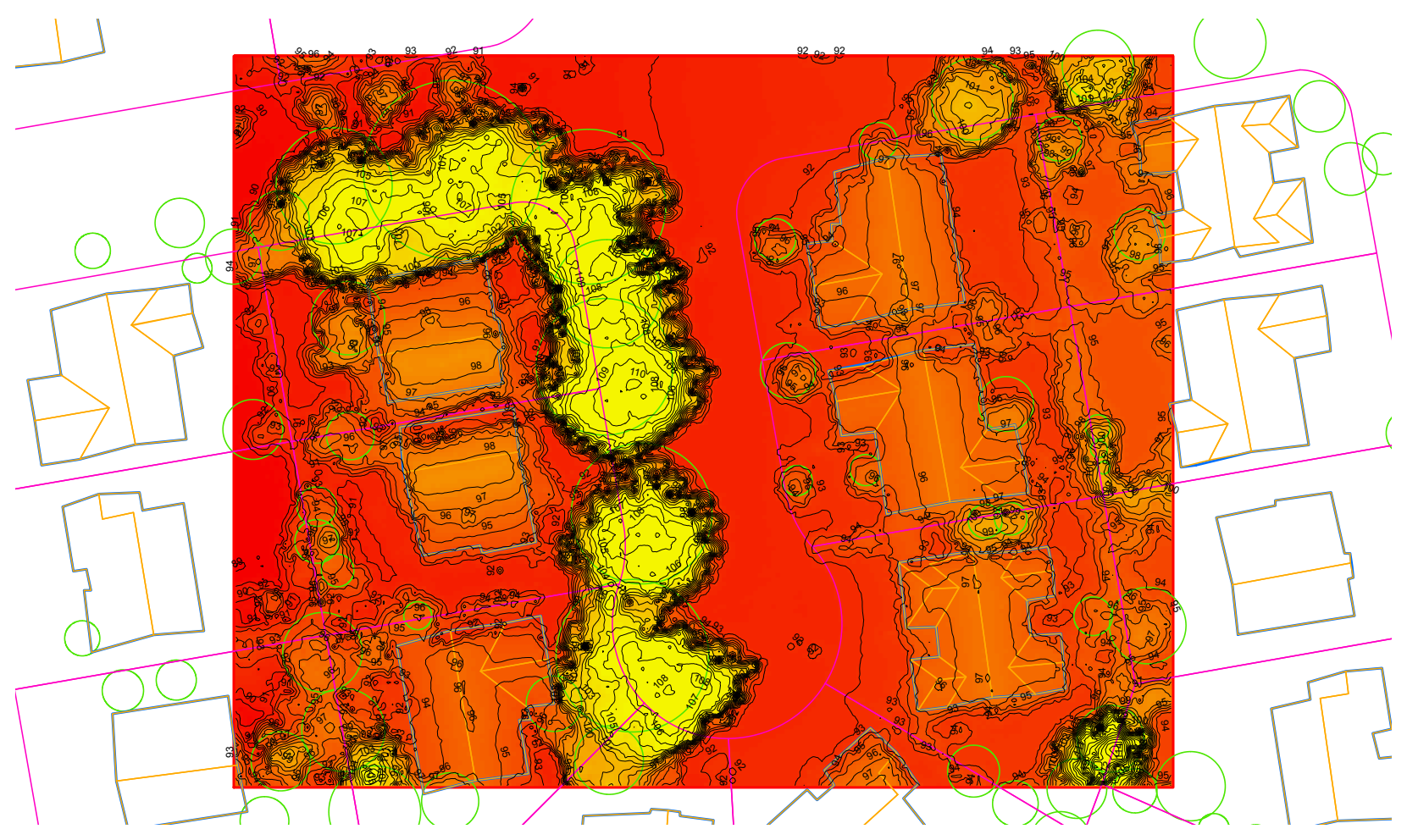

Figure 3: Detail of San Jose surface elevation raster (meters above sea level). 


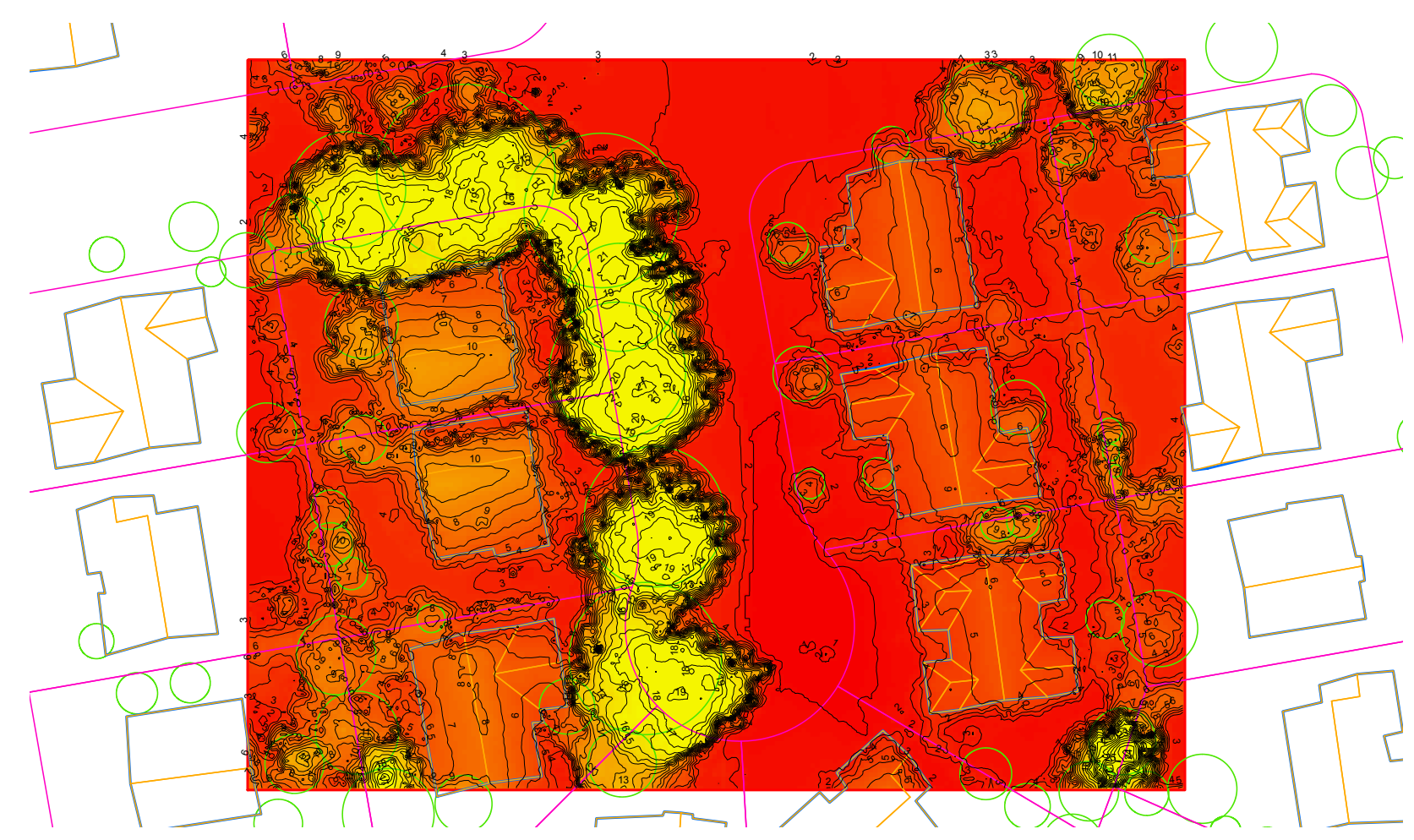

Figure 4: Detail of San Jose surface height raster (meters above ground).

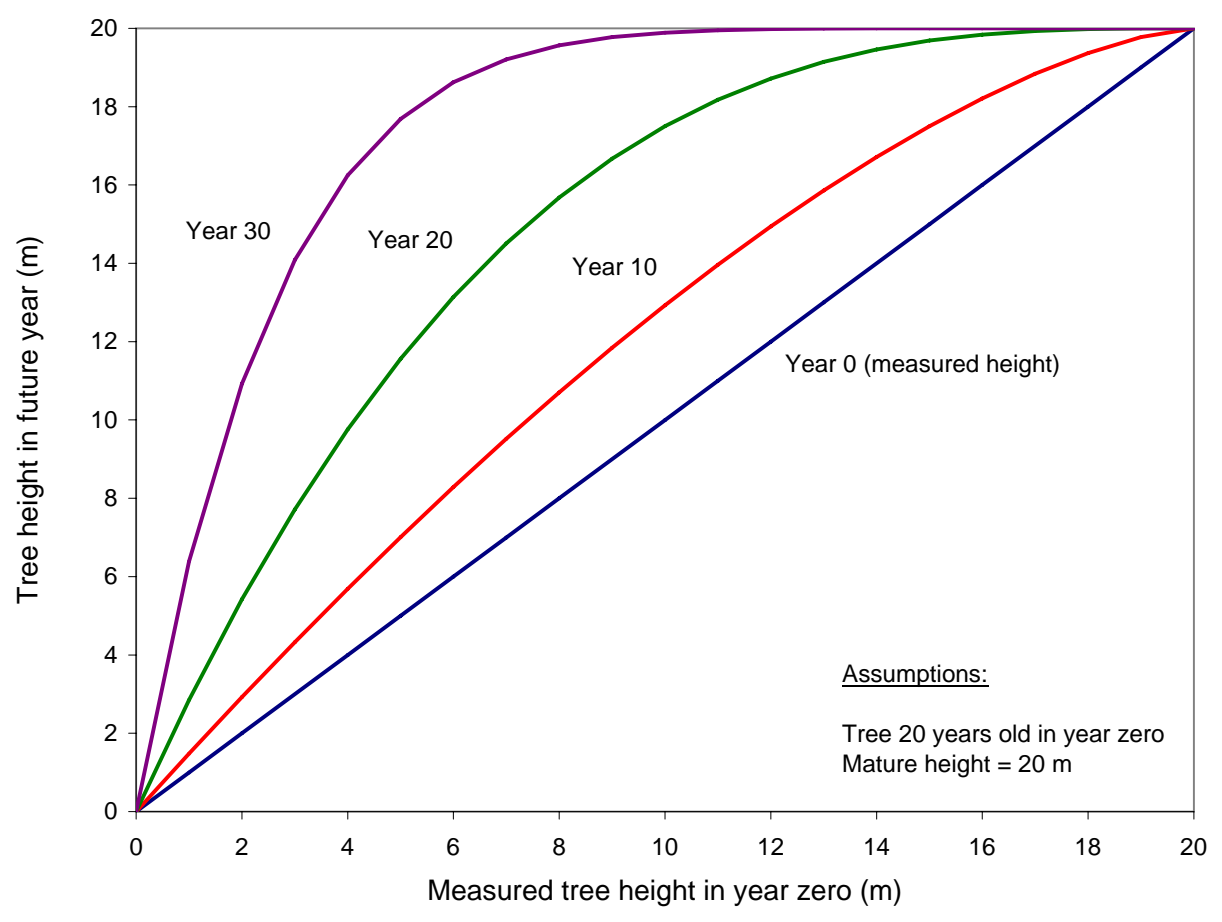

Figure 5: Asymptotic growth of tree that is 20 years old in year zero, assuming a mature height of $20 \mathrm{~m}$. 


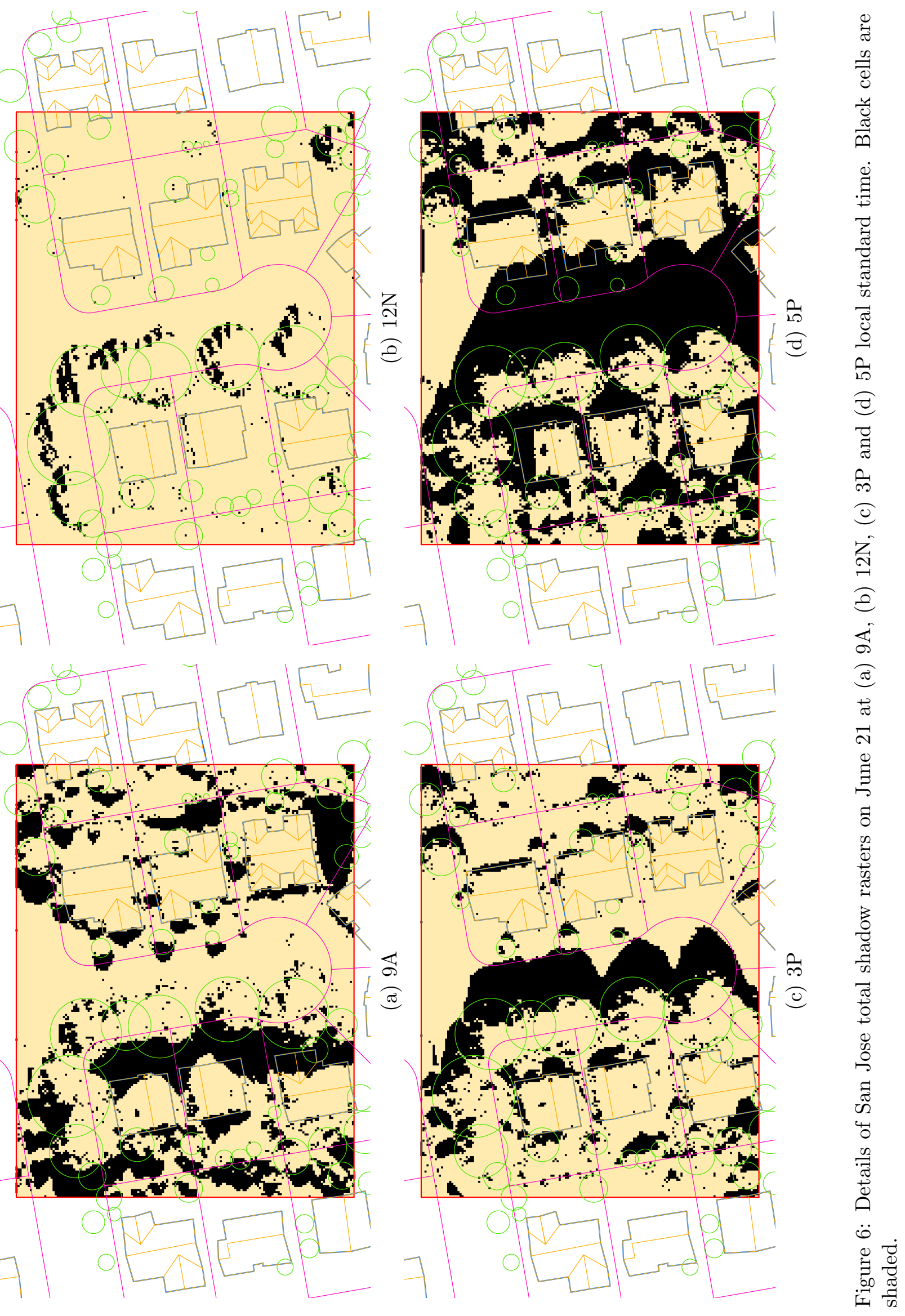




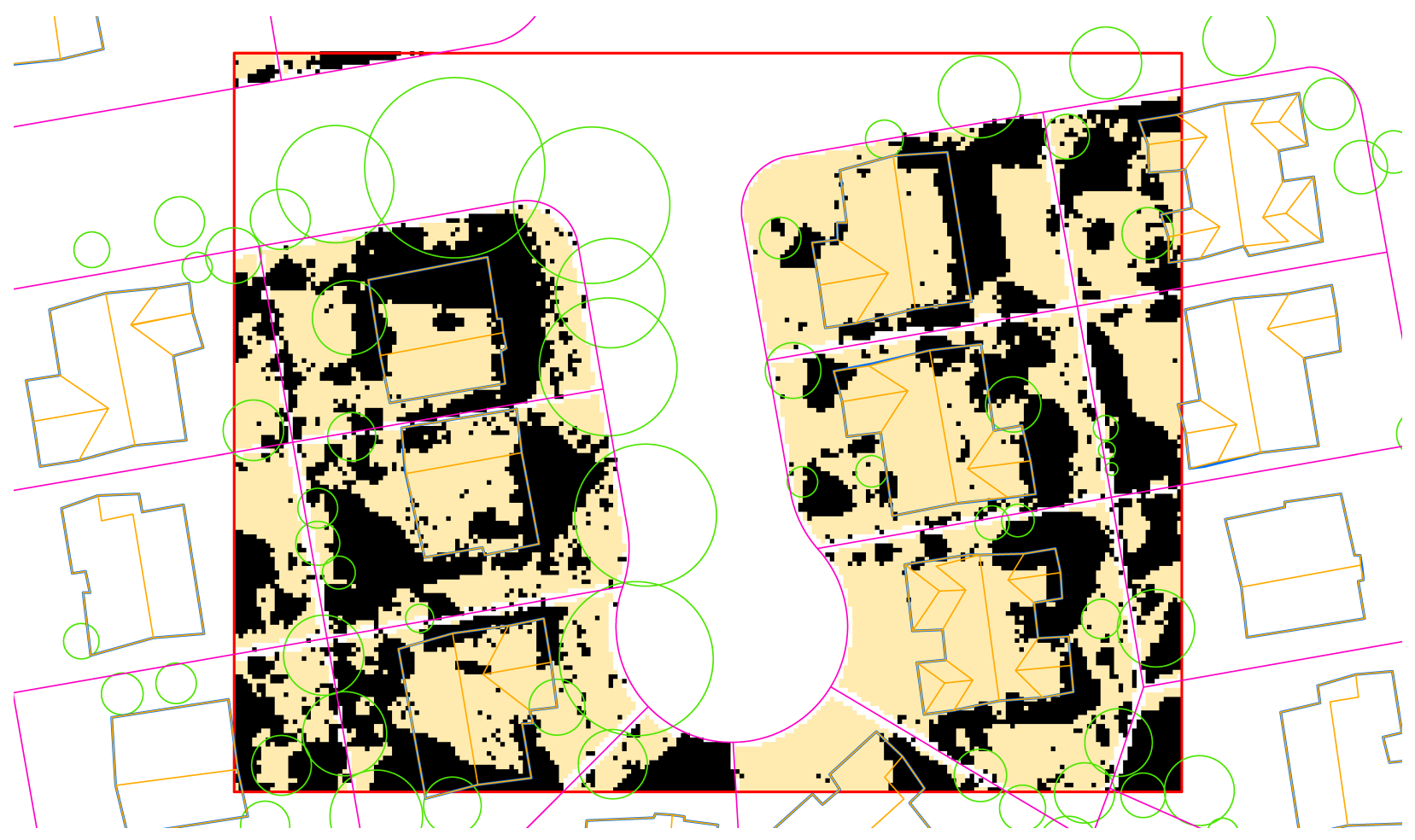

Figure 7: Detail of San Jose intraparcel shadow raster on June 21 at 5P LST. Black cells are shaded.

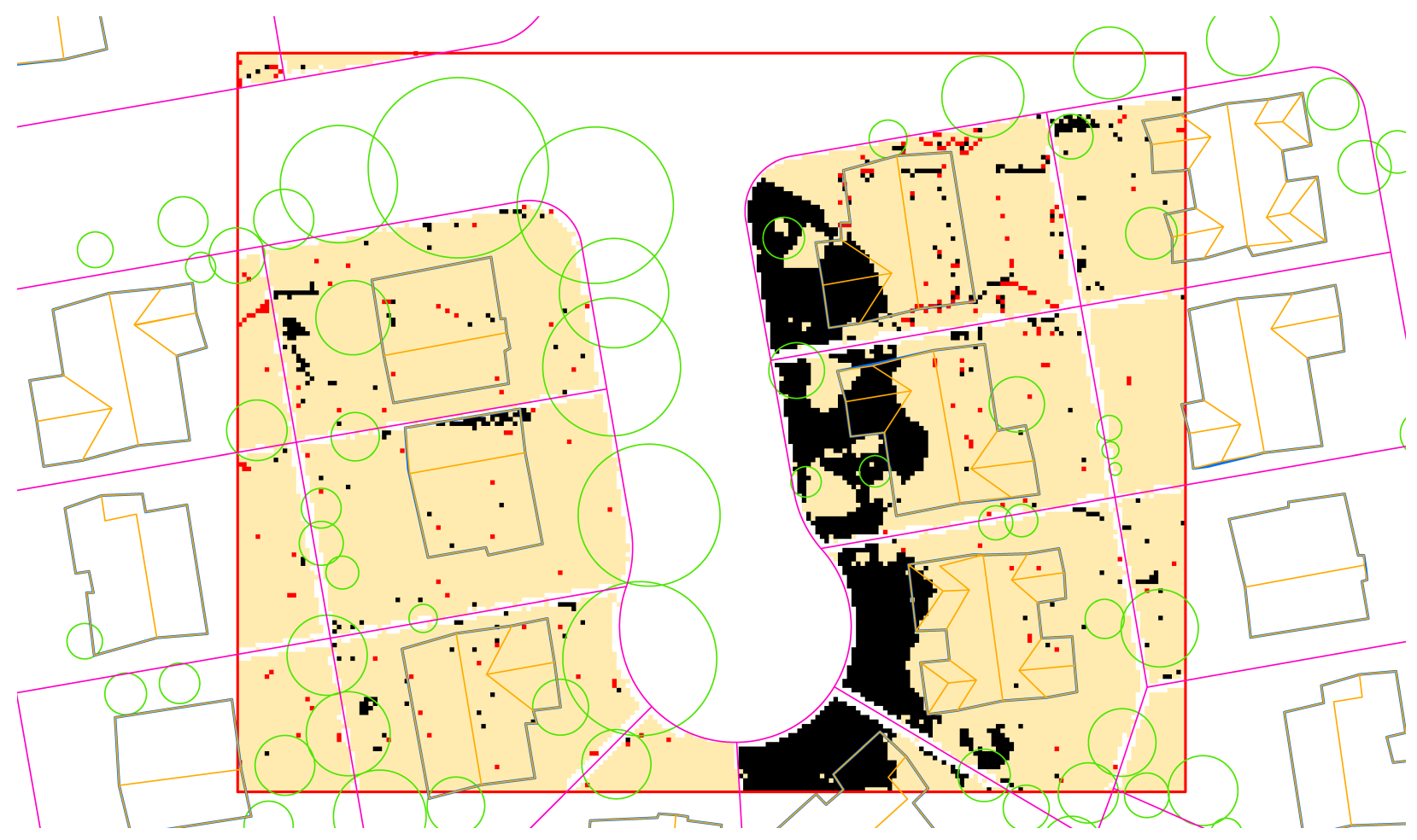

Figure 8: Detail of San Jose extraparcel shadow raster (total shadow raster minus intraparcel shadow raster) on June 21 at 5P LST. Black cells are shaded; isolated black cells and all red cells are computational artifacts. 

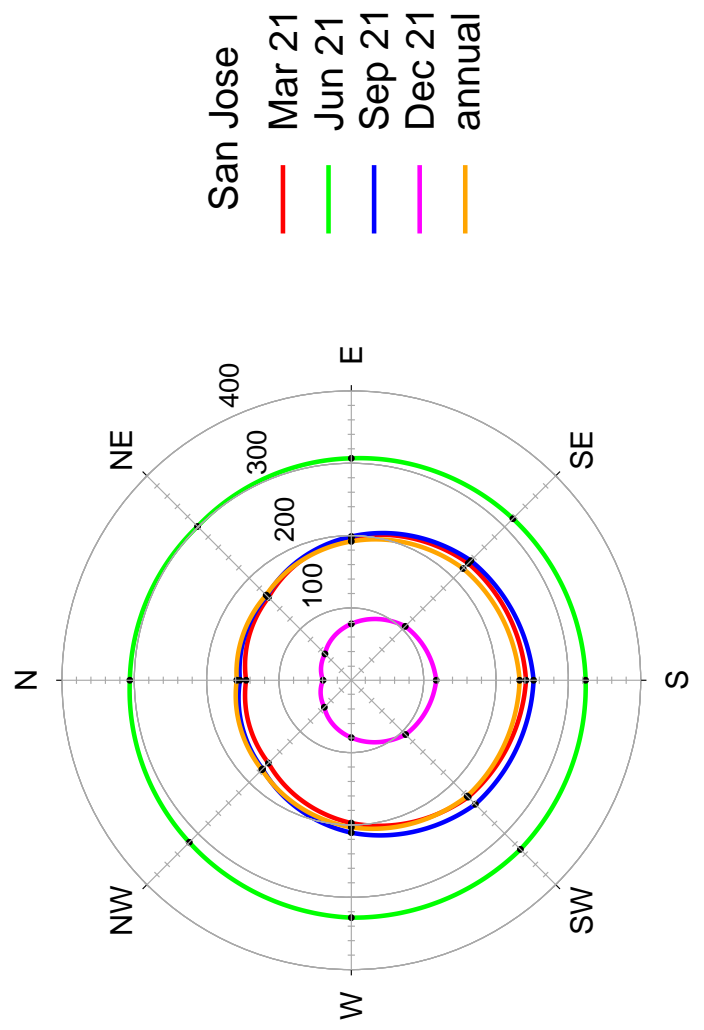

อ
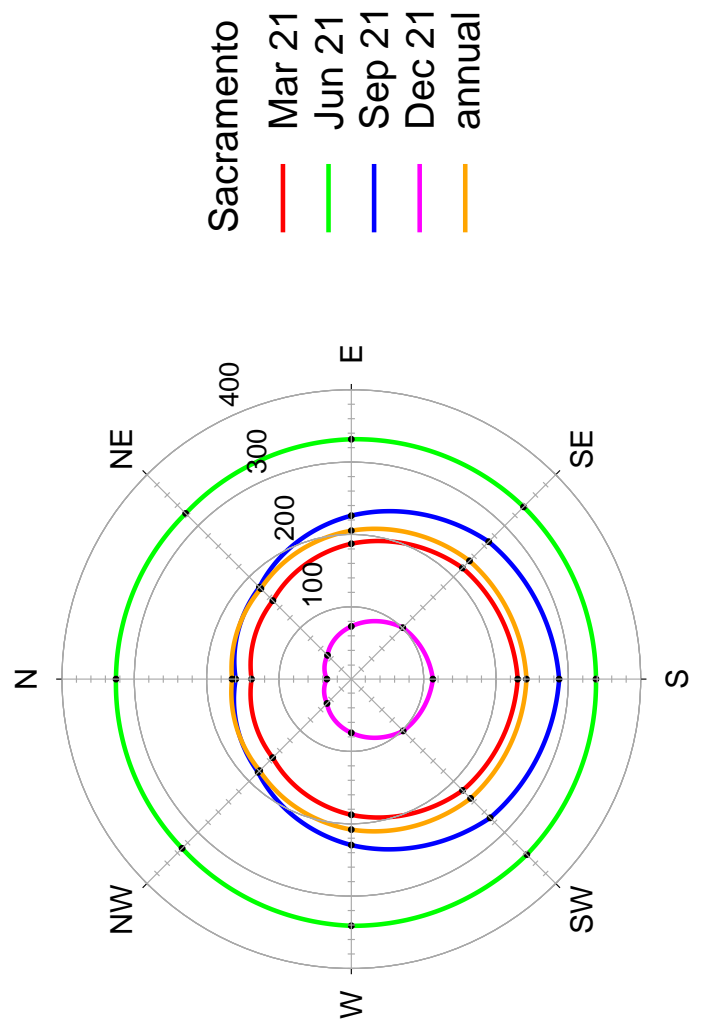
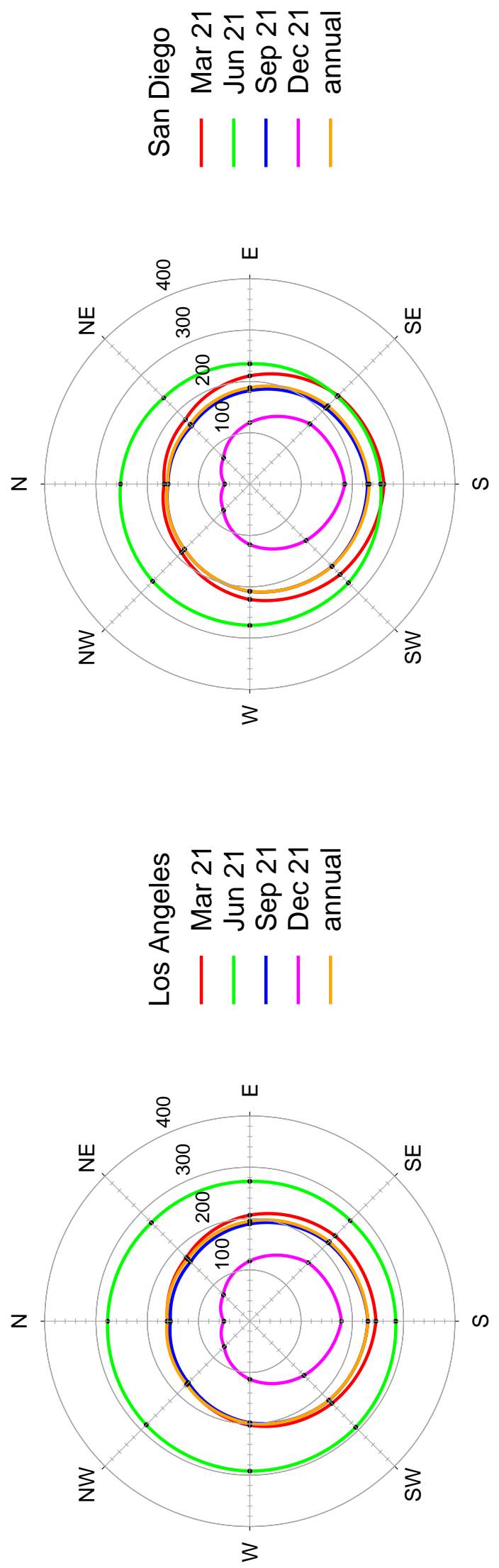

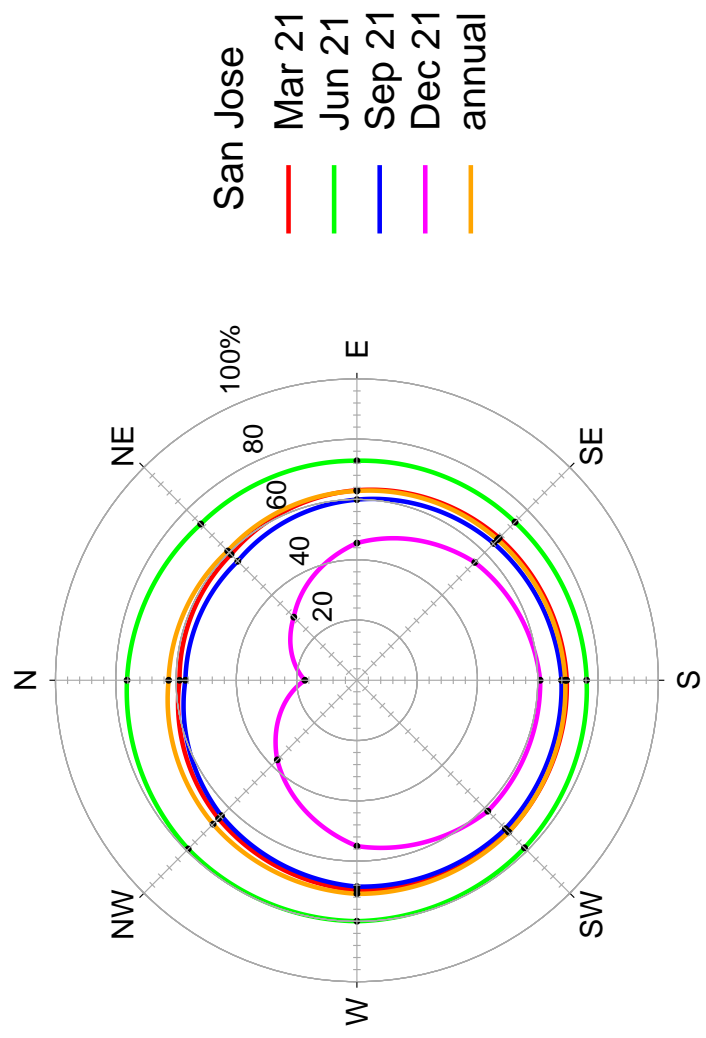

อ
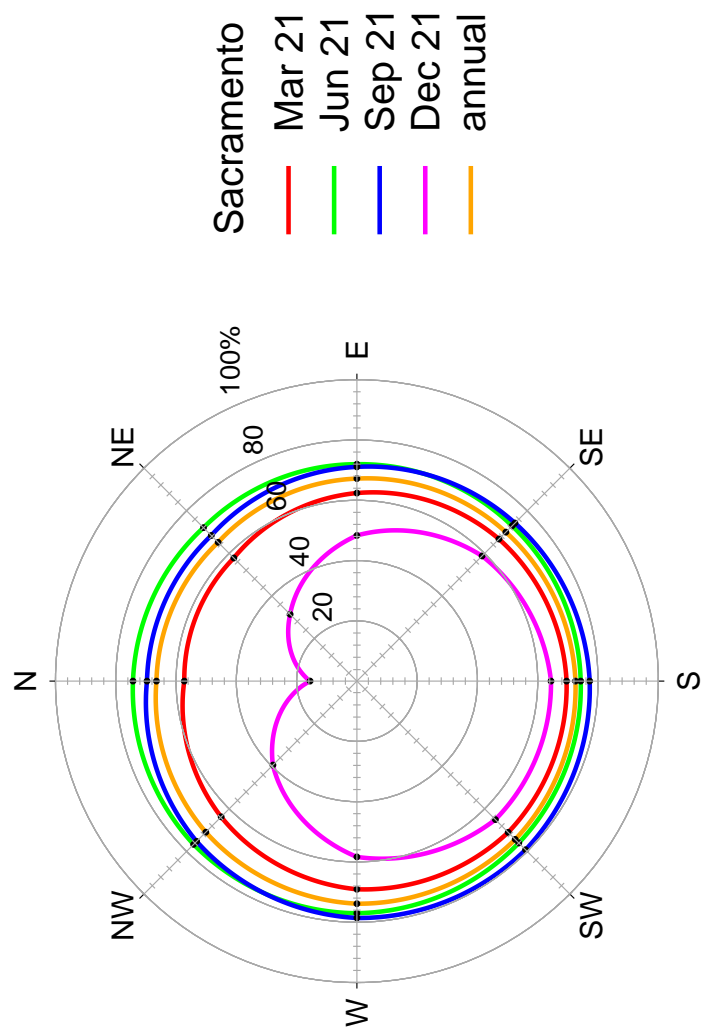

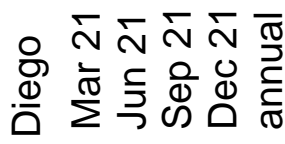
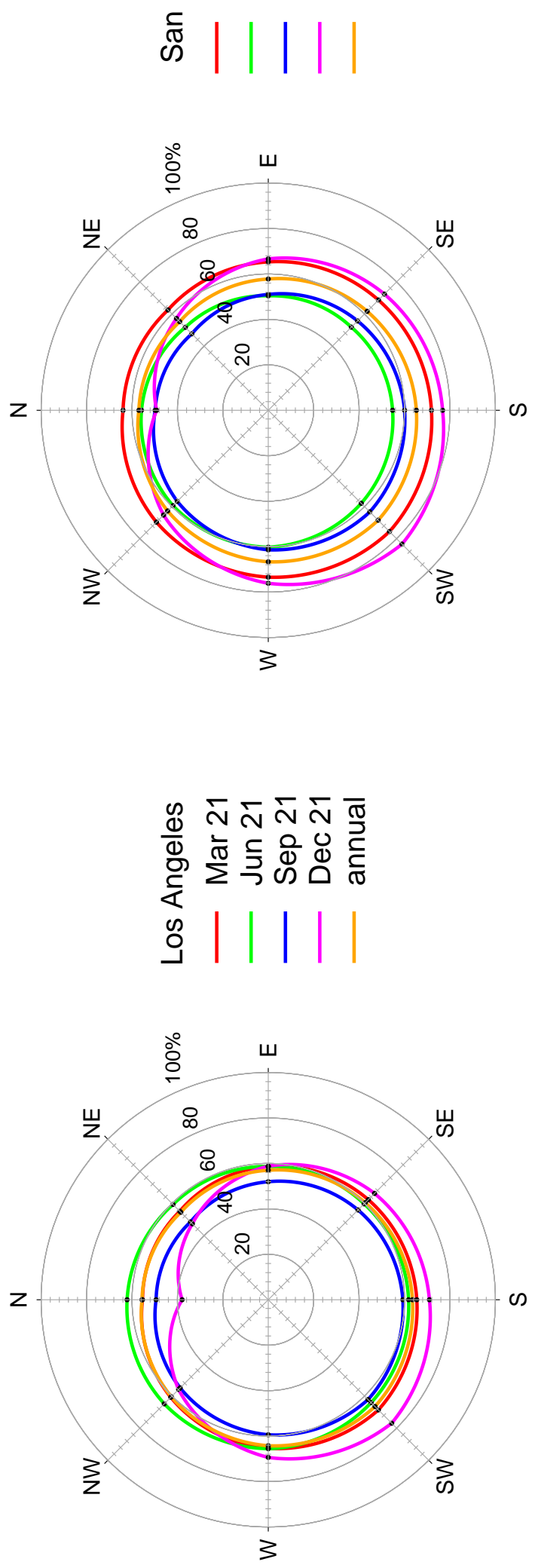


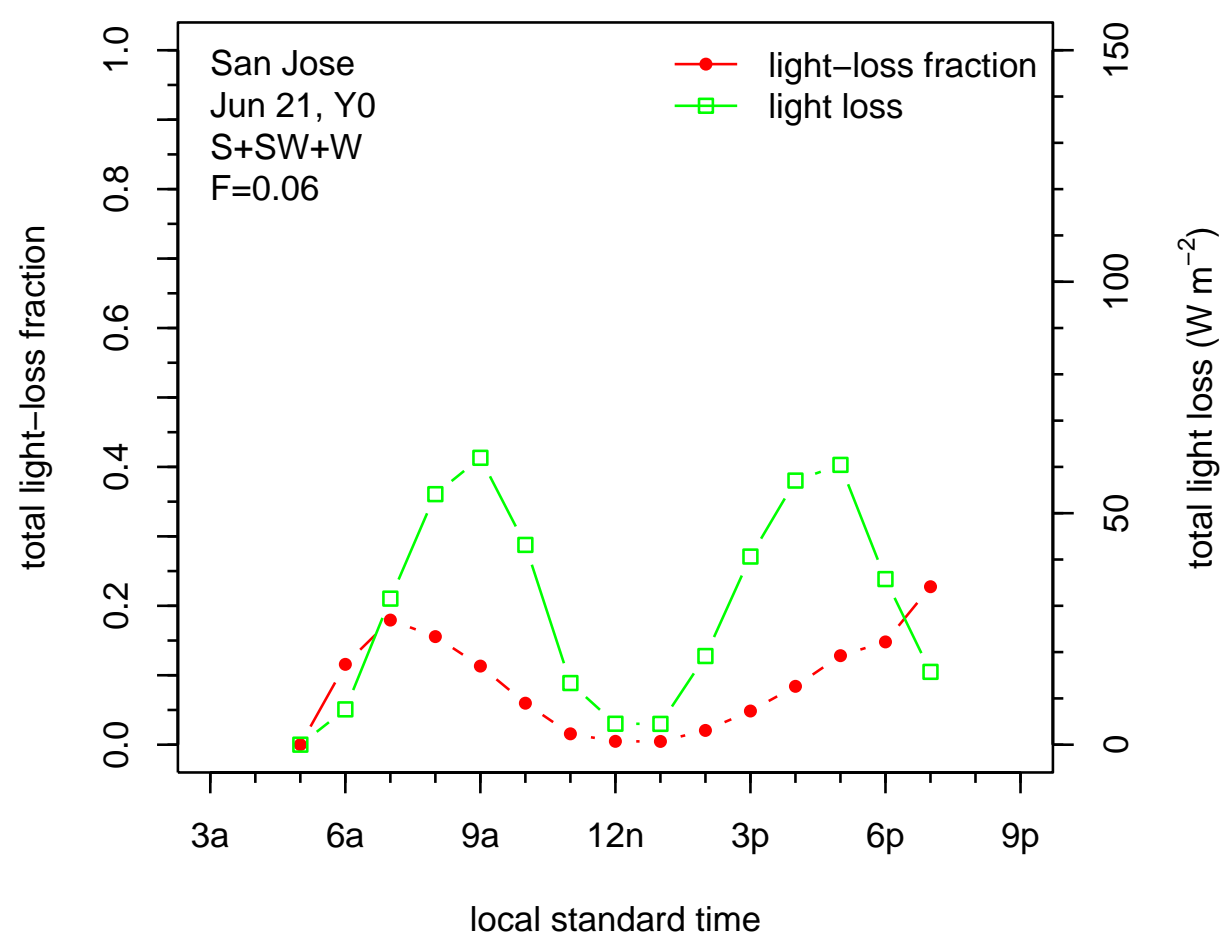

(a)

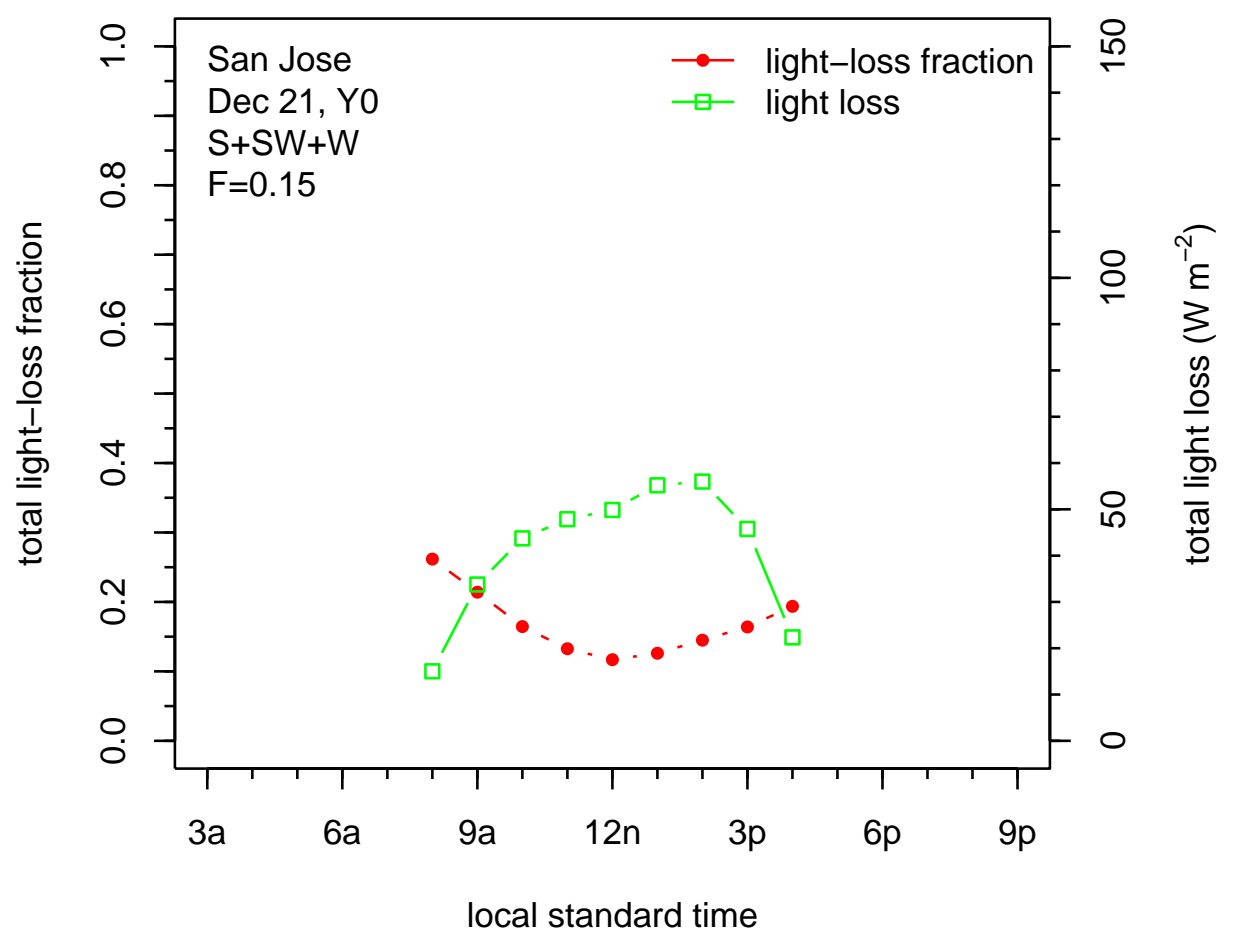

(b)

Figure 11: Year-zero on-hour total light loss fraction and total light-loss of S+SW+W roofing planes in San Jose on (a) June 21 (the summer solstice) and (b) December 21 (the winter solstice). Also shown is the daily total light loss fraction $F$. 

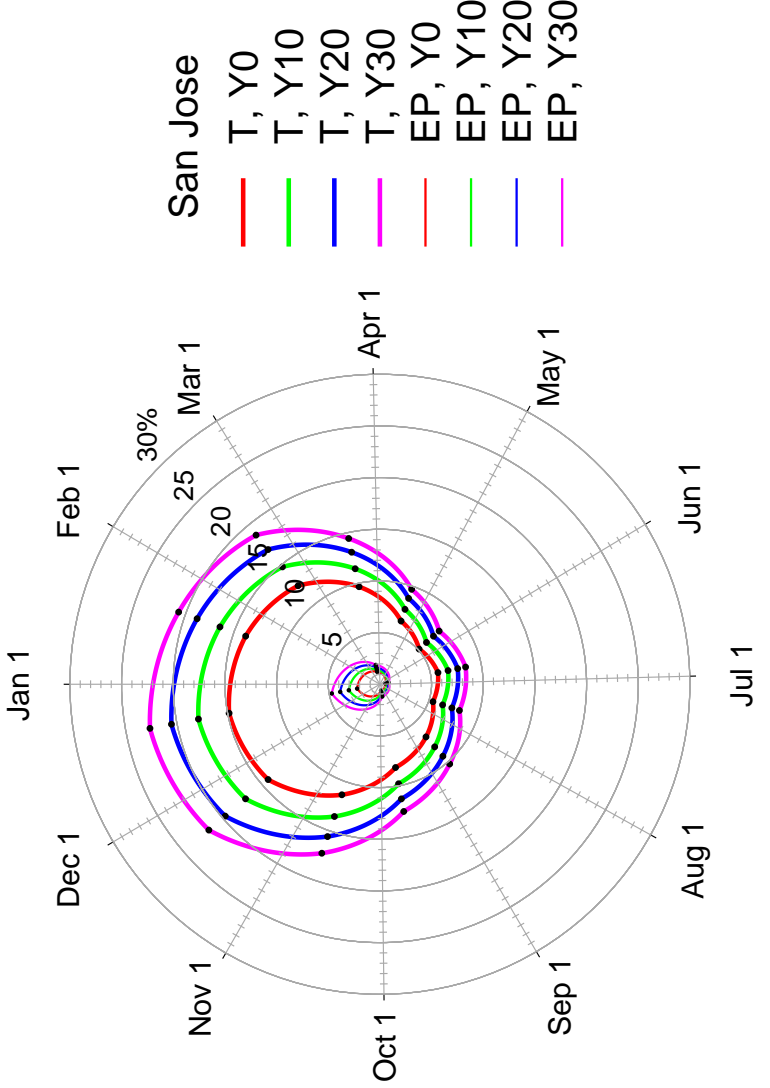

อ
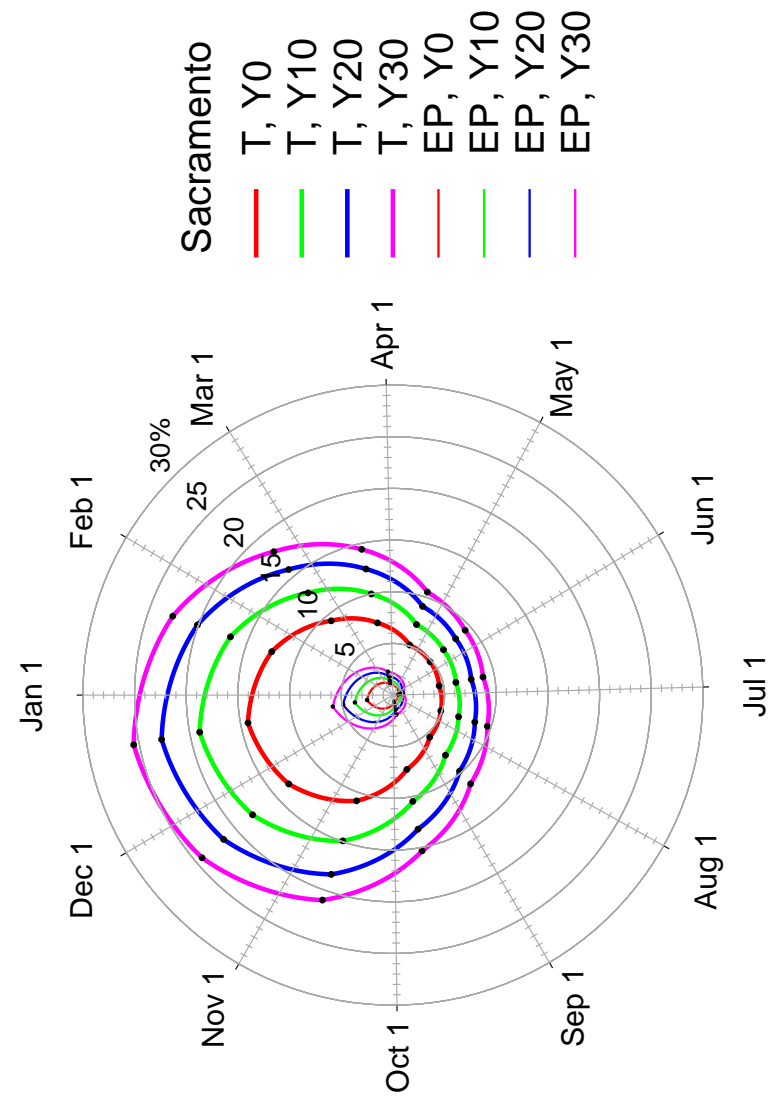

$\overbrace{}^{乛(}$

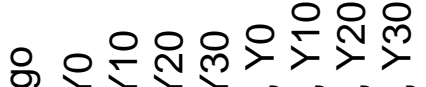

d $>>>>0^{\circ} 0^{\circ} 0$

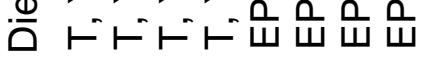

ल
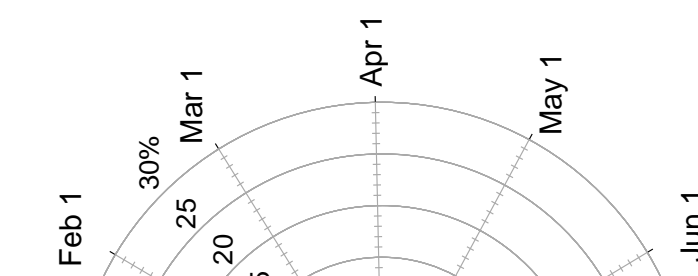

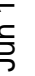

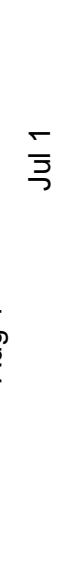

ซ
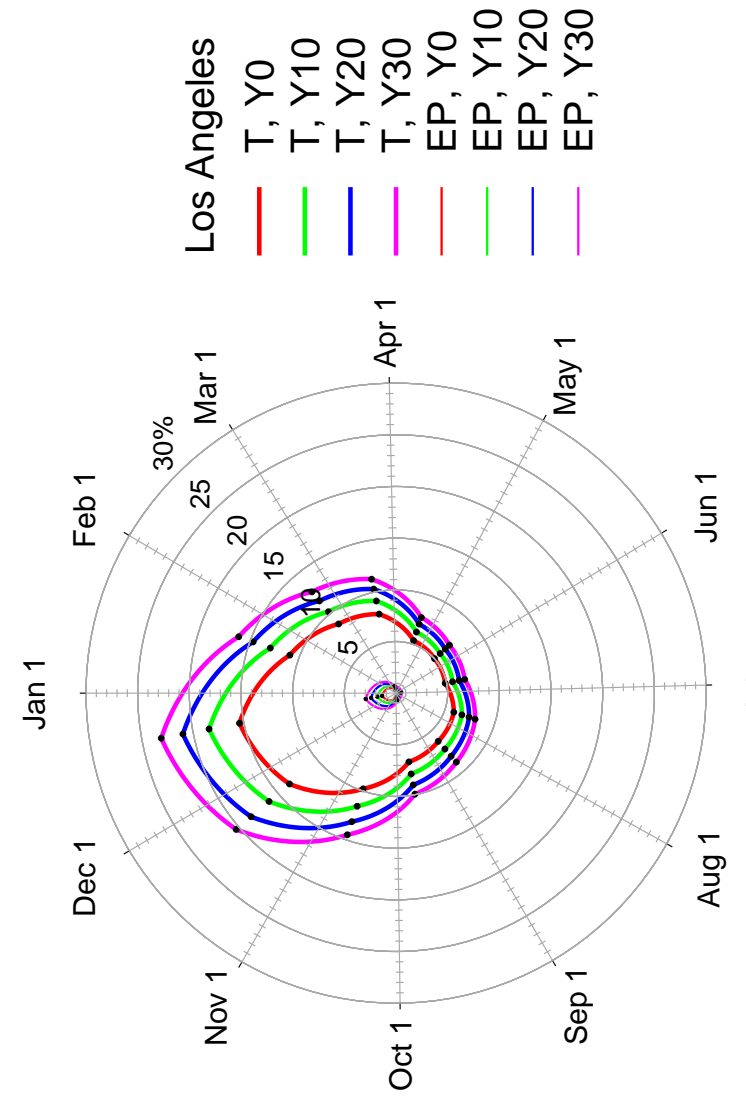

$\frac{-5}{5}$

$\bar{\Xi}$ 
드는 $\bar{N} \bar{N} \bar{N} \bar{N}$

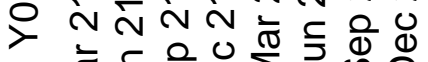

ब

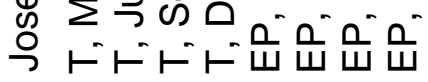

๓ั

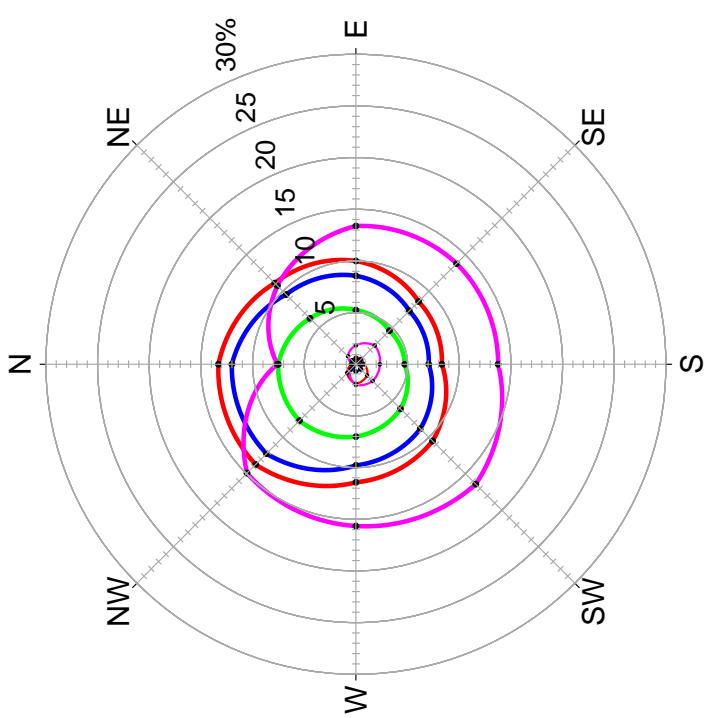

$\widehat{e}$

그는 $\bar{N} \bar{N} \bar{N} \bar{N}$

ํ.

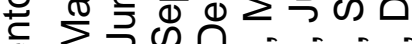

Ф

๕ั
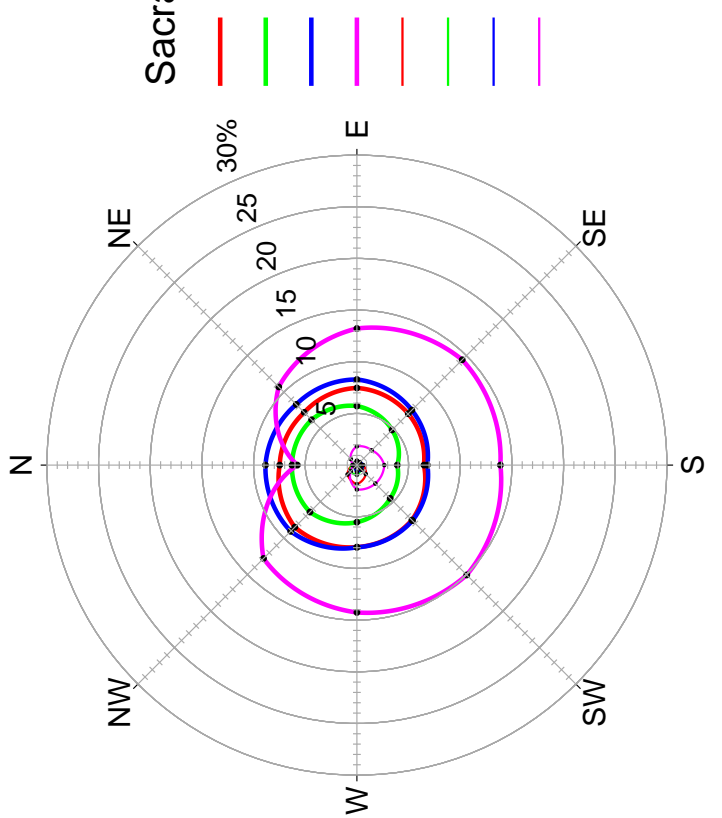

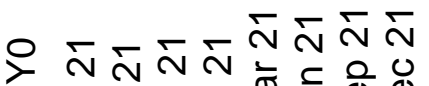

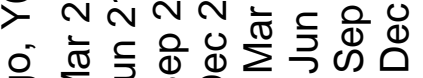

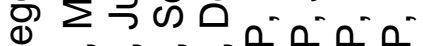

ジドドドドய岀ய

๓

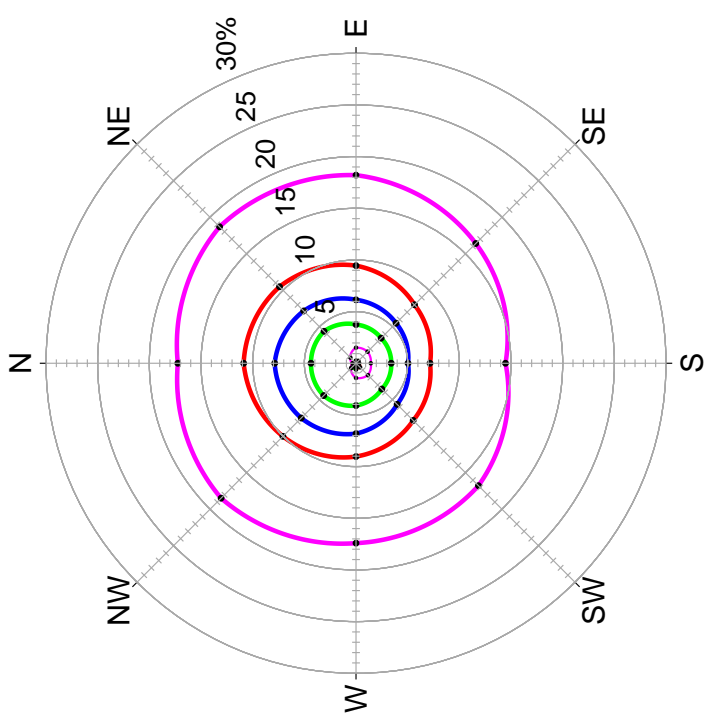

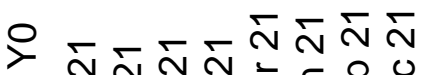

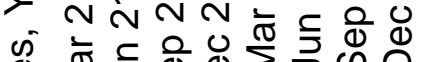

๗

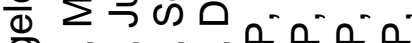

导ドドドド岀岀㞻
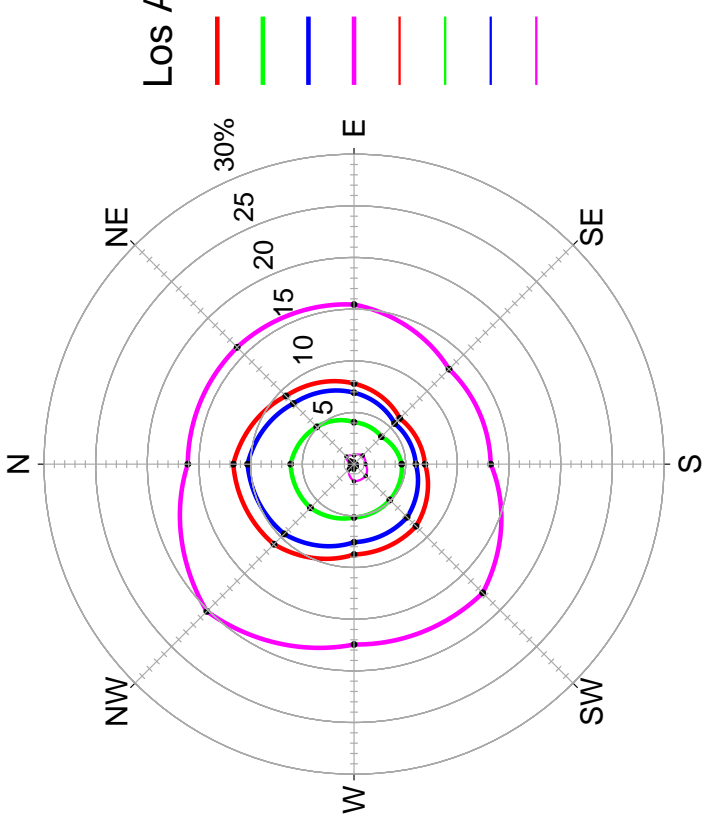


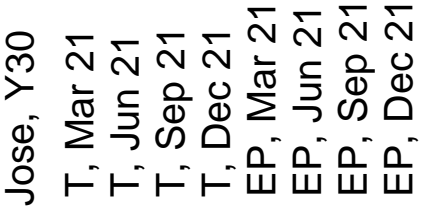
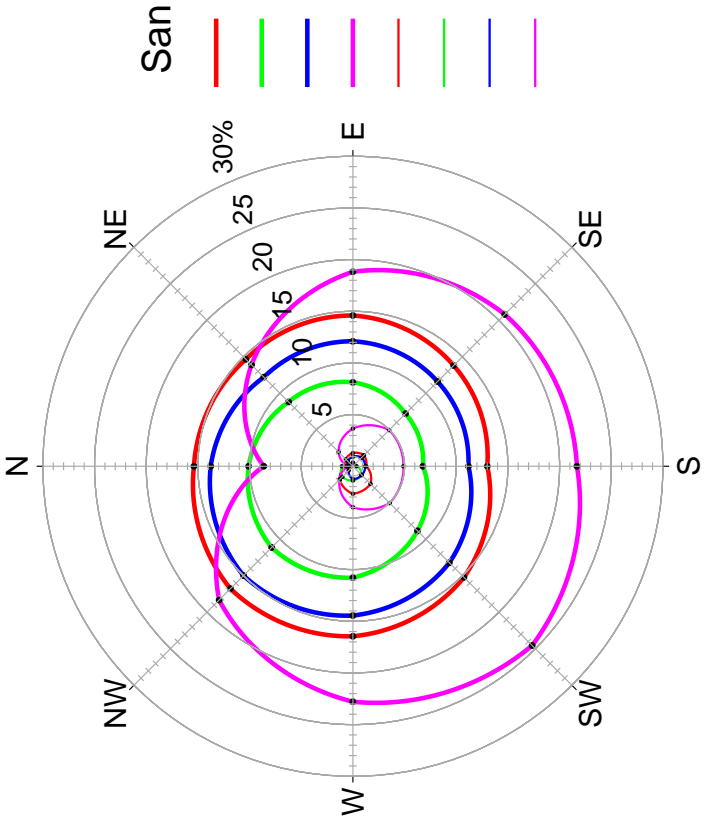

อ

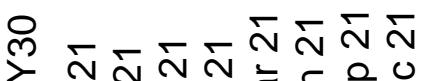

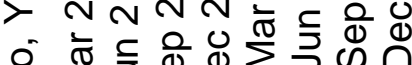

을 ‘

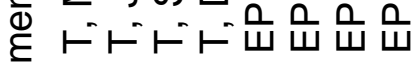
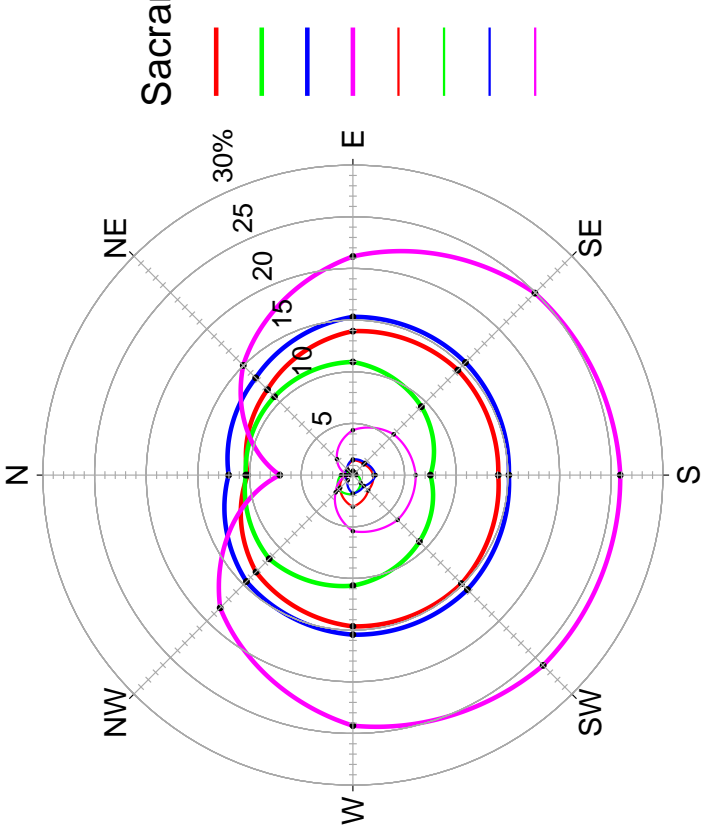

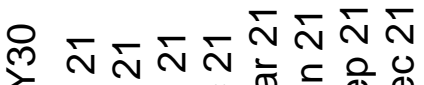

$>$ ส̄

일 ऊ

高ドドドドய岀岀
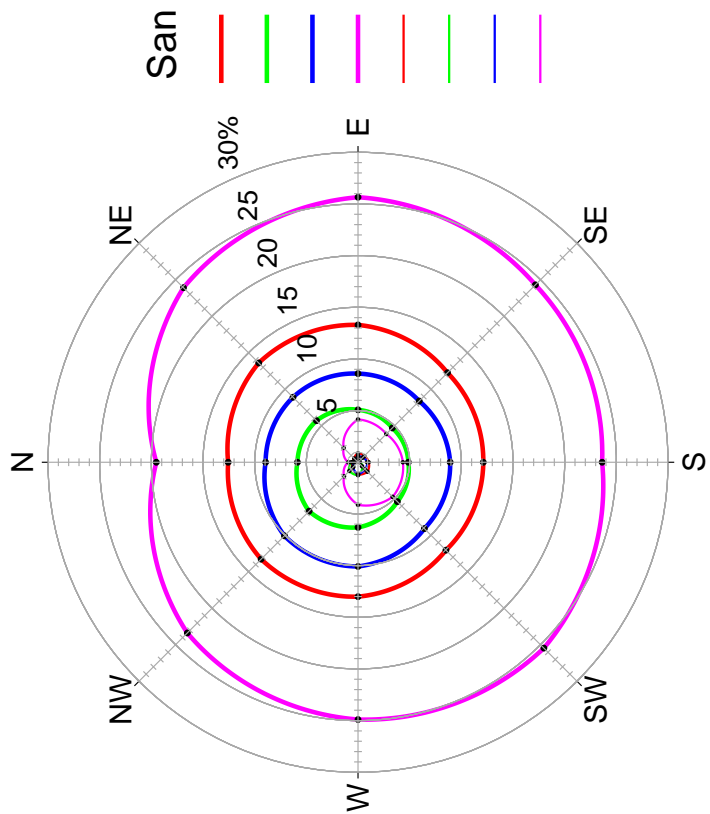

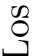

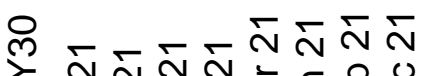

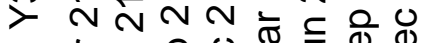

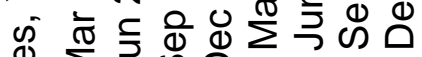

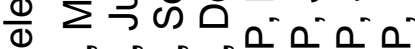

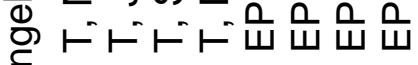

产

of
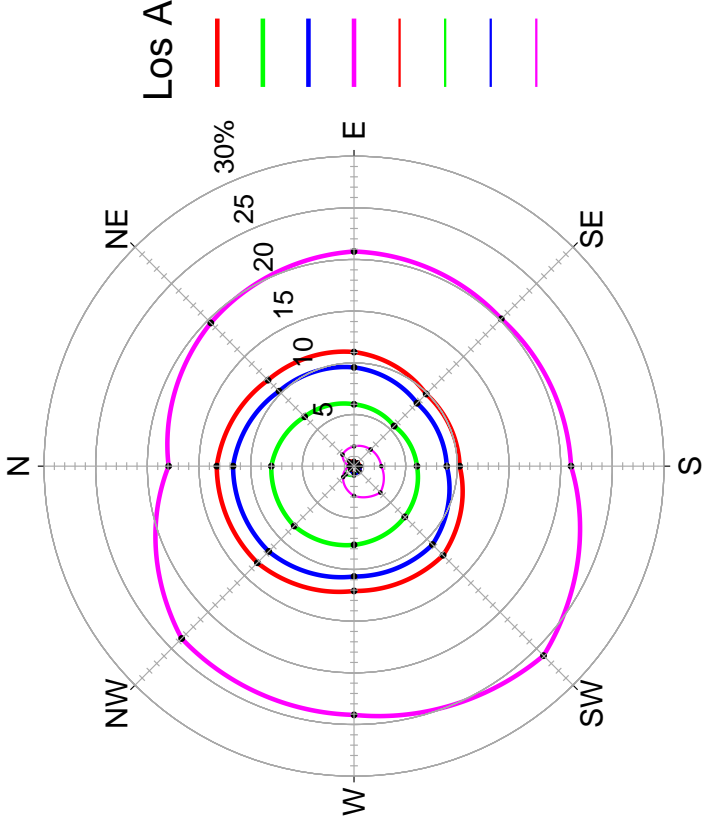

Æ

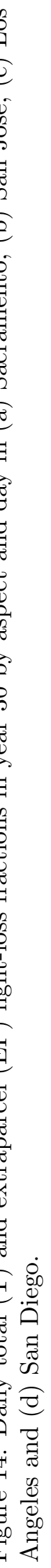

draft - do not quote, copy or circulate 

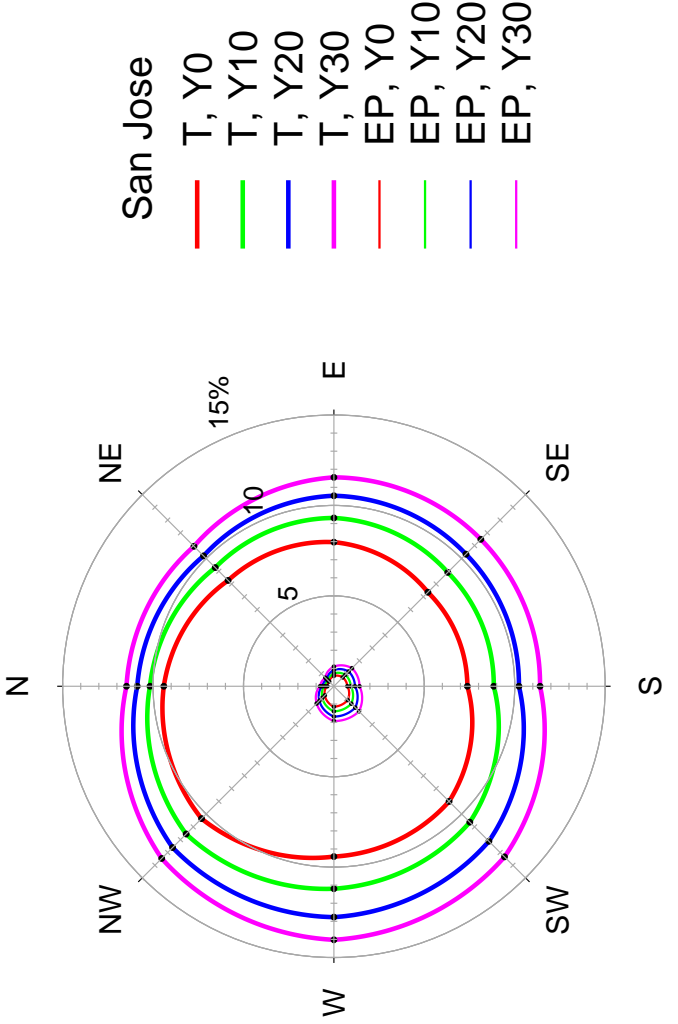

อ
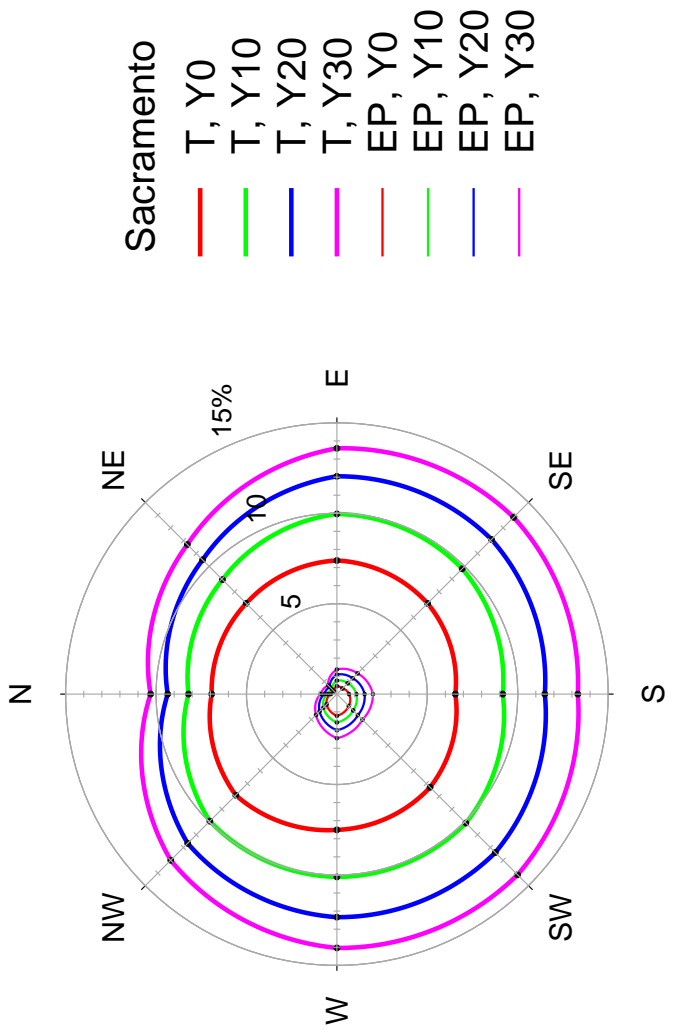

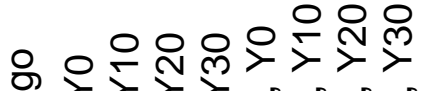

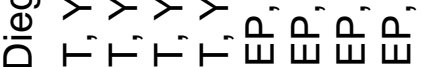

ल)
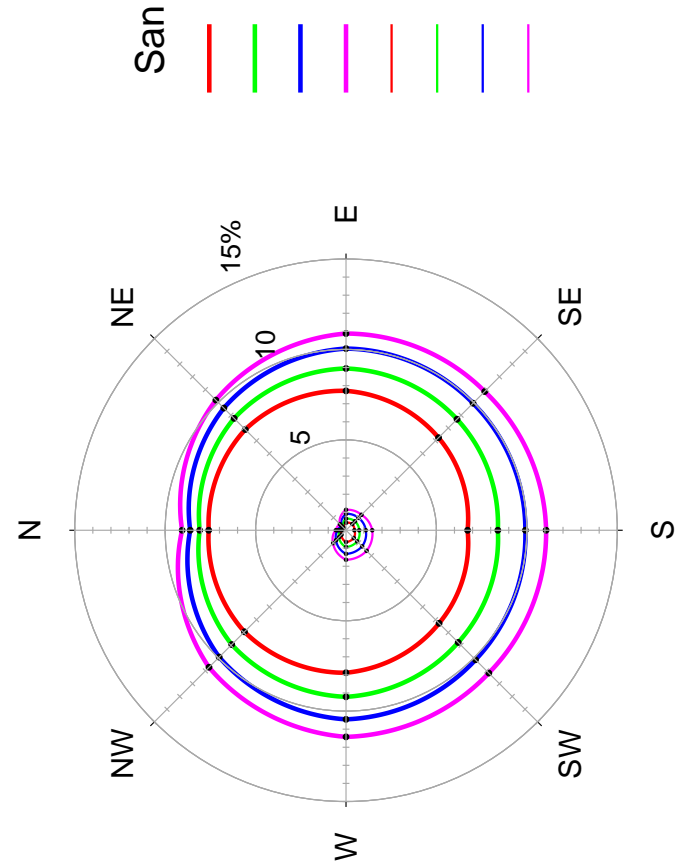

ซ

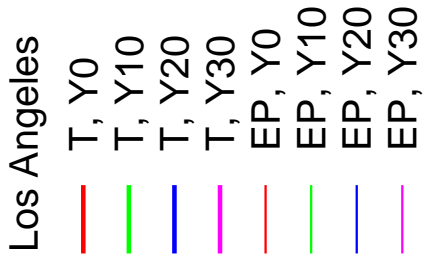

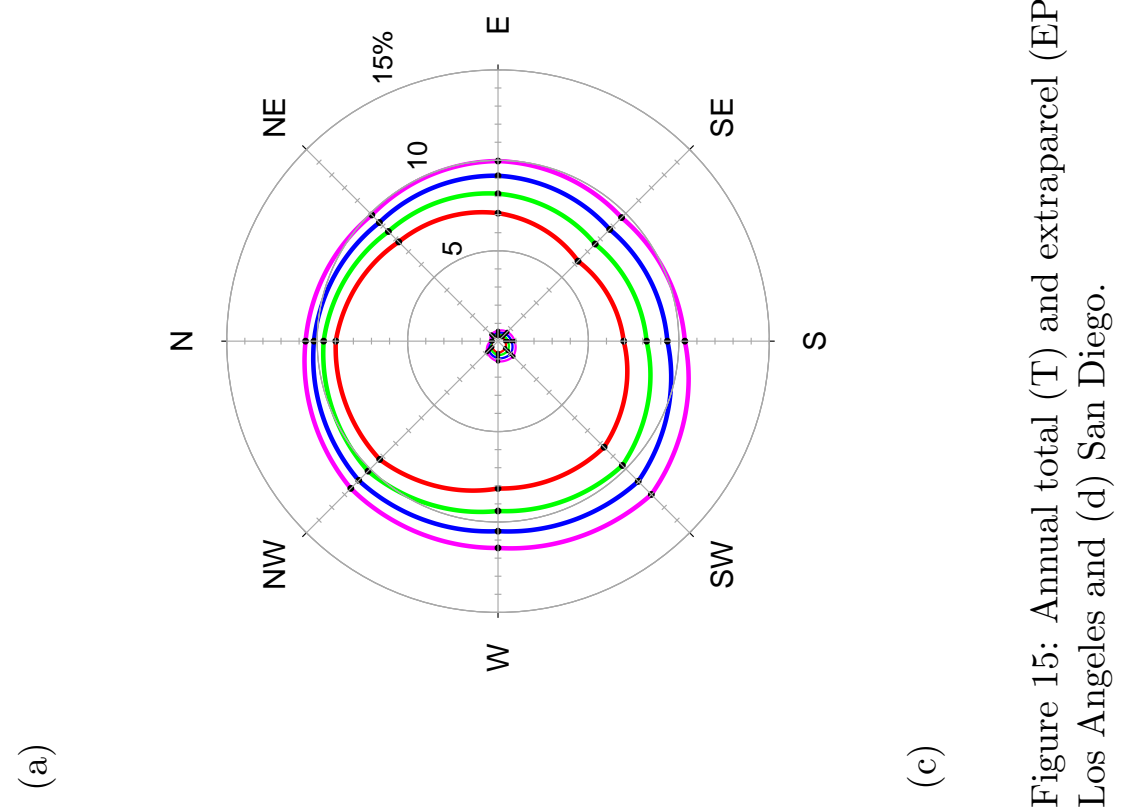



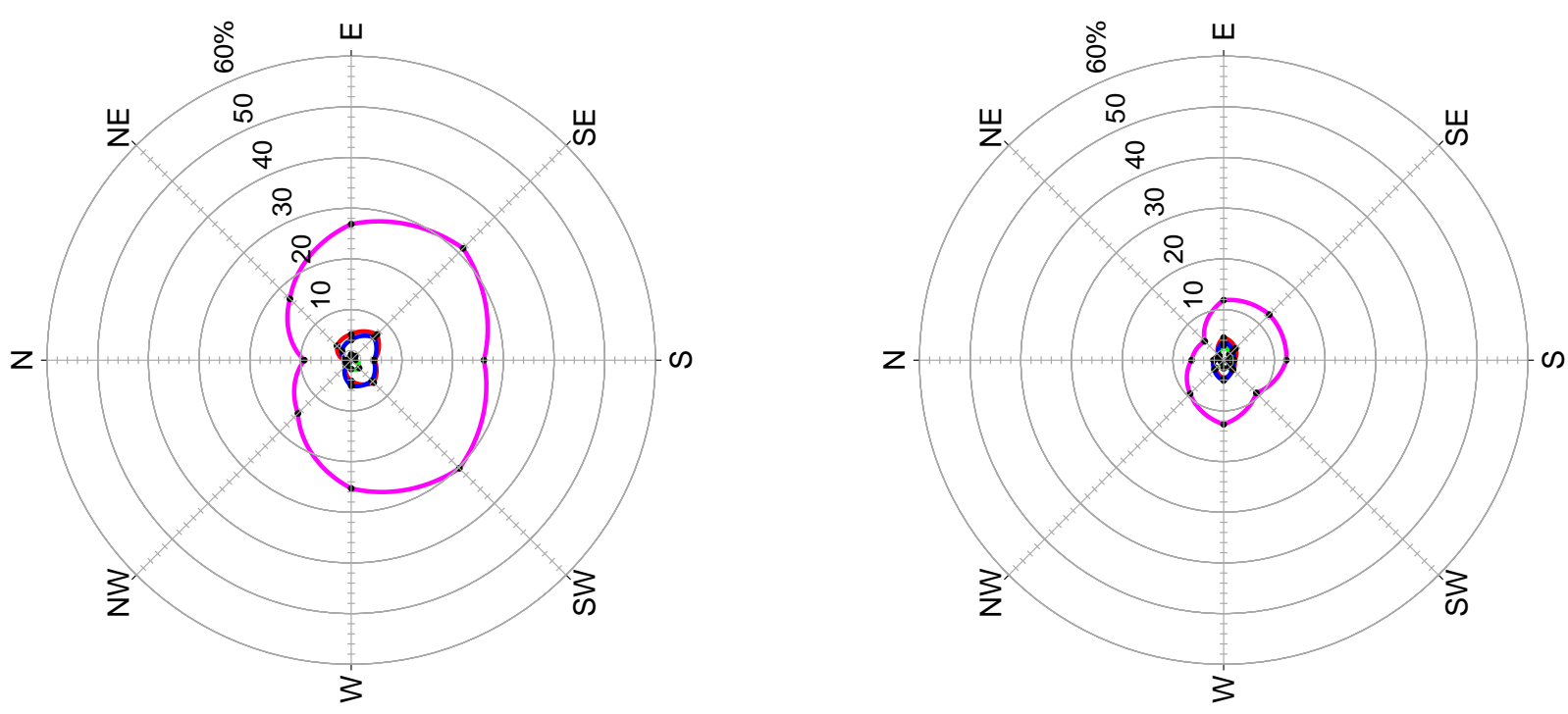

อ
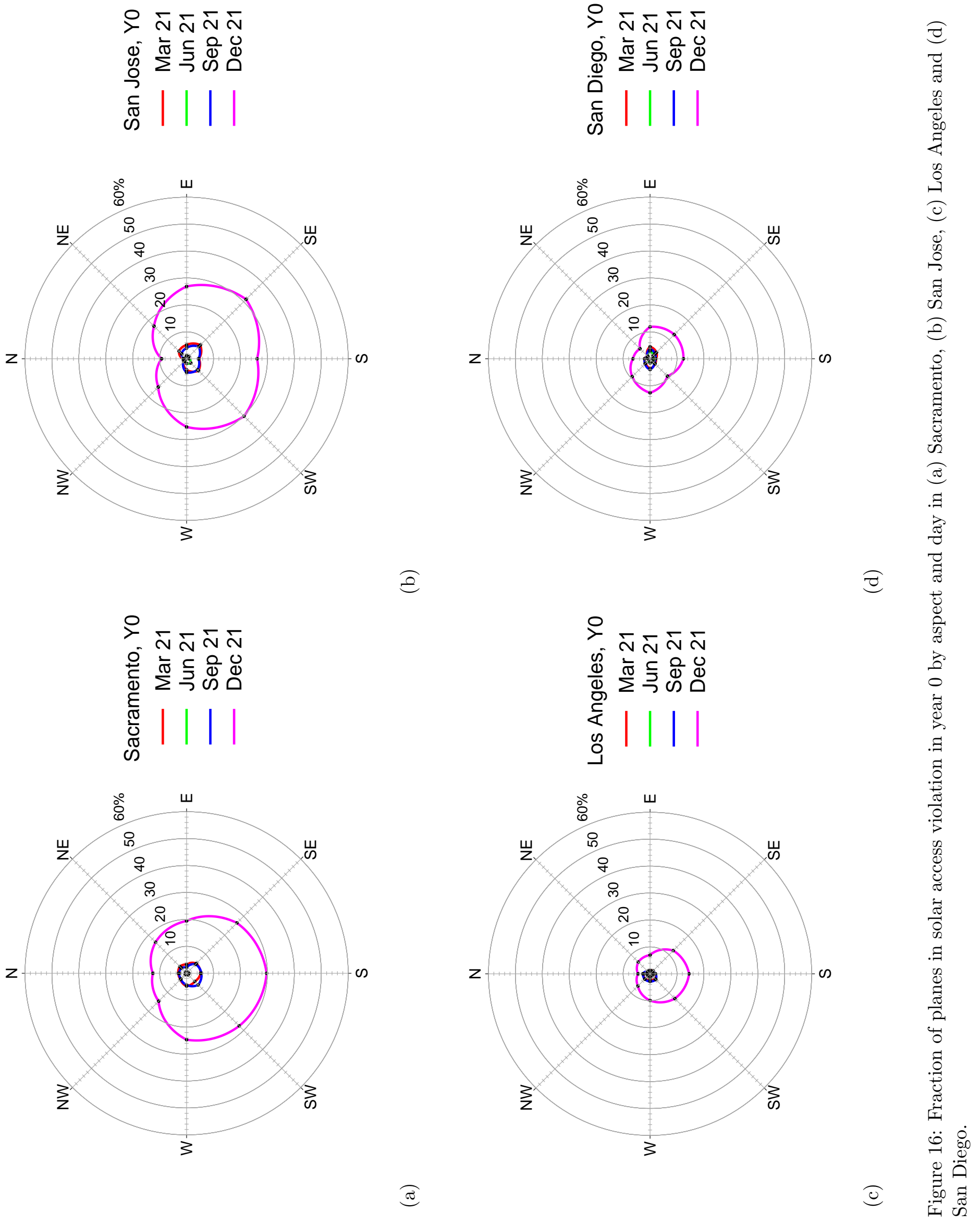

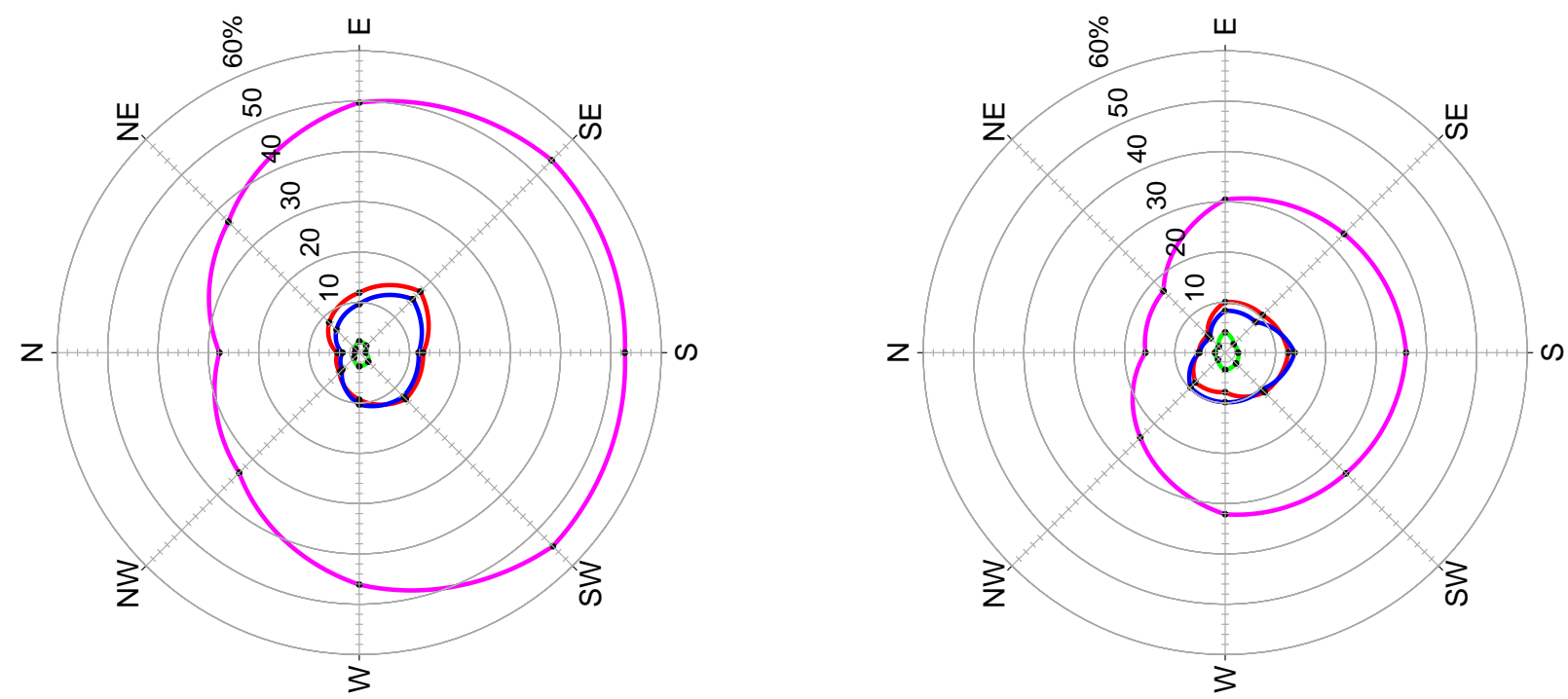

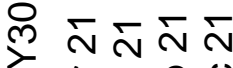

ㅇํㅊㅊำ

®

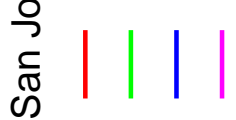

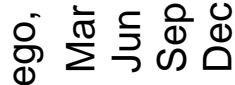

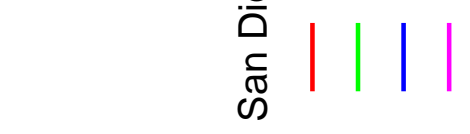

ت్ర
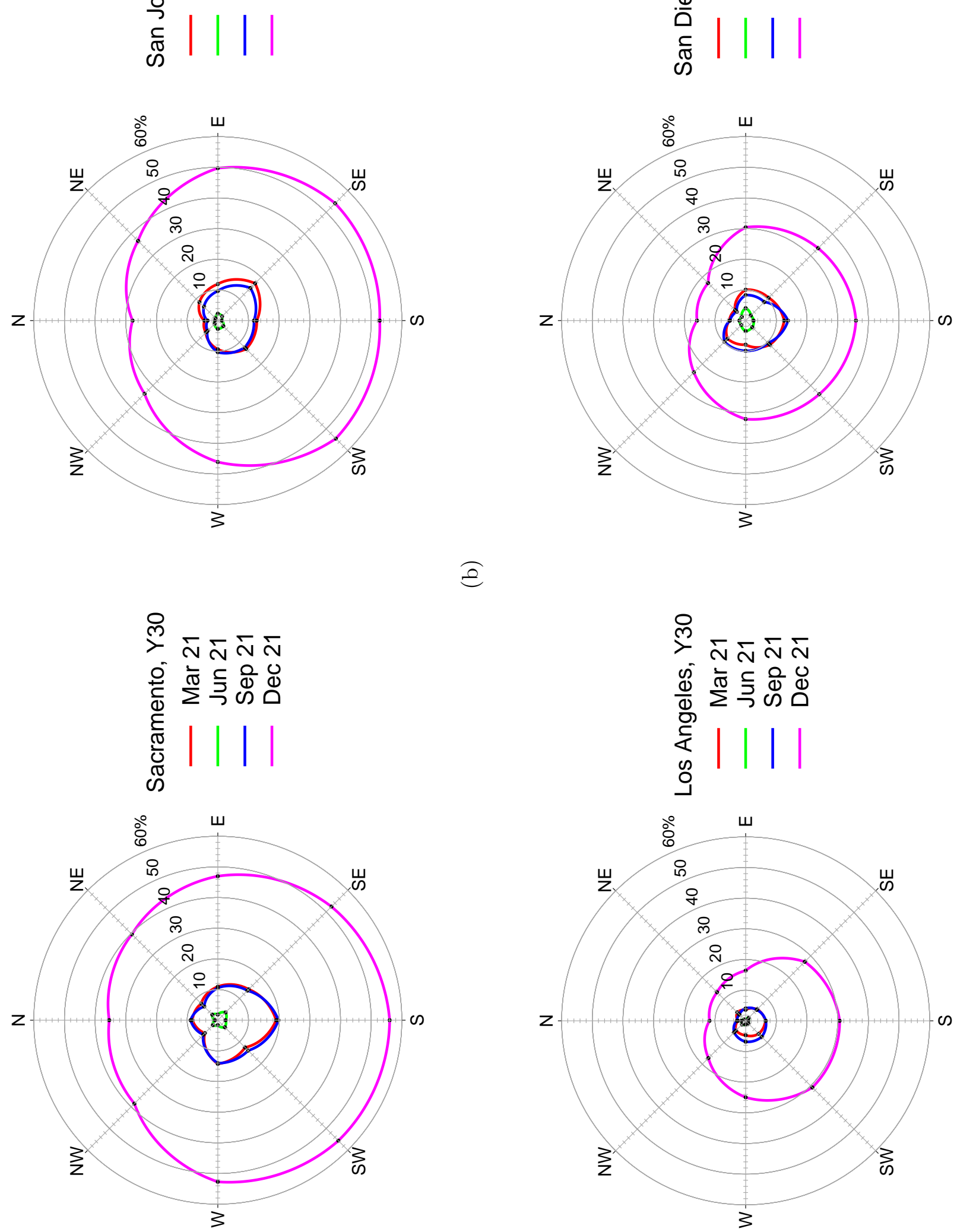

ฮ્త 